Revista lus et Praxis, Año 24, No 3, 2018, pp. 255 - 308

ISSN 0717 - 2877

Universidad de Talca - Facultad de Ciencias Jurídicas y Sociales

Por una responsabilidad civil de los medios de comunicación coherente con el

riesgo de divulgación de noticias falsas sobre personas públicas

Cristián Banfi del Río

Trabajo recibido el 13 de enero y aprobado el 19 de julio de 2018

\title{
Por una responsabilidad civil de los Medios de comunicación coherente con el riesgo de divulgación de noticias falsas sobre personas públicas
}

\author{
FOR A TORT LIABILITY OF THE MEDIA WHICH IS CONSISTENT WITH THE RISK OF \\ SPREADING FALSE NEWS CONCERNING PUBLIC PERSONS
}

CRISTIÁn BANFI del Río*

\section{RESUMEN}

Este artículo postula que los Medios de comunicación deberían responder del daño causado a la honra de personas públicas sólo si éste emana de un ejercicio extremadamente abusivo de su libertad de expresión, esto es, mediante la publicación de información falsa a sabiendas, con indiferencia temeraria hacia su veracidad o culpa lata.

\section{ABSTRACT}

This article argues that the media should be liable for harm caused to the public persons' reputation only if it derives from an extremely abusive exercise of their freedom of speech, that is, through the publication of information with knowledge of its falsity, with reckless disregard of its truthfulness or with gross negligence.

Palabras Clave

Riesgo, responsabilidad civil, periodismo, personas públicas

KEY WORDS

Risk, tort liability, journalism, public persons

\section{Introducción}

La doctrina y la jurisprudencia chilena -constitucional y judicial-coinciden en que los Medios de comunicación social (los "Medios") deben responder de los

\footnotetext{
* PhD, University of Cambridge. Profesor Asociado de Derecho Civil, Universidad de Chile. Pío Nono 1, Providencia, Santiago, cbanfi@derecho.uchile.cl. Este artículo integra el Proyecto Fondecyt Regular 1170094. Agradezco los valiosos comentarios de los árbitros anónimos que revisaron una versión preliminar de este manuscrito. Todos los errores son, por cierto, míos.
} 
daños que irrogan al crédito, honra o reputación ajena', más allá del art. 2331 del Código Civil chileno ("CC")2.

Pues bien, la hipótesis que procuraré demostrar es que la responsabilidad civil imputable a los Medios que transmiten información concerniente a personas públicas, no debe ceñirse a esa regla sino que debería ser enteramente excepcional.

Este aserto se funda en que, el ejercicio del derecho a la libertad de expresión y que la Constitución Política de la República ("CPR") reconoce a los Medios", afecta inexorablemente a quienes son objeto de noticias.

Este efecto colateral, por nocivo que pueda percibirse a priori, es un riesgo que el sistema jurídico tolera. Salvo, claro está, que provenga del ejercicio abusivo de aquel derecho.

Luego, el derecho a la libertad de expresión no es absoluto sino que debe ejercerse de modo compatible con el derecho a la honra ajena que la CPR igualmente reconoce y garantiza ${ }^{4}$.

Según la doctrina nacional dominante, la transmisión de noticias falsas relativas a cualquier persona, hace civilmente responsables a los Medios si éstos han actuado dolosa o culpablemente. Ella entiende, así, que el término "abusos" -contenido en el art. $19 \mathrm{~N}^{\circ} 12 \mathrm{CPR}$ - alude a un delito o cuasidelito civil, aun si el perjudicado es una persona pública.

Por el contrario, en las líneas que siguen sostendré que las personas públicas, atendidas las atribuciones y funciones que les son confiadas, están constantemente expuestas al escrutinio de la opinión pública.

Por este motivo, el abuso del derecho a la libertad de informar que tiene la virtud de suscitar la responsabilidad patrimonial de los Medios hacia esta clase de personas, requiere una calificación adicional, a saber: es necesario que el

\footnotetext{
1 "El término honra tiene dos acepciones: a) subjetivo: es el aprecio que cada uno tiene de sí mismo, y b) objetivo: que es la reputación o buena fama que los terceros tienen de uno, amparando la Constitución este segundo aspecto, pues el primero queda en efecto en el fuero interno del sujeto; en cambio, el objetivo forma parte de la convivencia social y ésta es la que regula el Derecho, toda vez que constituye la proyección de la dignidad del ser humano": Corte de Apelaciones de Santiago, rol № 983-1993, 31 de mayo de 1993, cons. $7^{\circ}$. El honor, a diferencia de la honra, "corresponde a la autoestima, a la consideración o, quién sabe, si a la vanidad o al orgullo que cada cual tiene de sí mismo": CEA (2012), p. 201.

${ }^{2}$ Las referencias a artículos se entienden hechas al CC.

3 "La Constitución asegura a todas las personas: $12^{\circ}$. La libertad de emitir opinión y la de informar, sin censura previa, en cualquier forma y por cualquier medio, sin perjuicio de responder de los delitos y abusos que se cometan en el ejercicio de estas libertades, en conformidad a la ley, la que deberá ser de quórum calificado". Art. 19 № 12 inc. 10, CPR.

4 "La Constitución asegura a todas las personas: $4^{\circ}$. El respeto y protección a la vida privada y a la honra de la persona y su familia". Art. $19 \mathrm{~N}^{\circ} 4, \mathrm{CPR}$.
} 
periodista demandado haya difundido una noticia falsa dolosamente -esto es, con intención de lesionar la honra de dichos sujetos, sea como un fin, sea como un medio para otro fin, a menudo buscando lucrar de su actividad- o con total indiferencia sobre si lo informado es verídico o falso, esto es, incurriendo en una especie de dolo eventual o, al menos, en la culpa lata que la ley equipara a aquél en materias civiles, incluyendo, por cierto, la responsabilidad civil extracontractual ${ }^{5}$.

Para tal propósito me fundaré en argumentos que han sido latamente elaborados por una corriente minoritaria de la doctrina chilena, de la que formo parte, y que impulsa la restricción de la responsabilidad por los daños que emanan no sólo del ejercicio del derecho a la libertad de expresión, sino también de la libertad de competir en cuanto manifestación de la libertad de empresa ${ }^{6}$.

En efecto, la libertad de competir inevitablemente afecta a una o más personas, pero ello no es justificación suficiente para atribuir al triunfador el deber de resarcir los daños experimentados por los rivales comerciales a quienes derrotó.

Las libertades de expresión y de competir operan como causales de justificación del menoscabo que causan a terceros, confiriendo a sus titulares un "derecho a dañar", a menos que abusen de éste.

Sin embargo, dada la trascendencia de estas libertades en el sistema económico y político imperante, el abuso susceptible de desencadenar la responsabilidad civil de los titulares de las mismas, no puede ni debe concebirse del modo ortodoxo -vale decir, como un acto anormal o descuidado- sino que exige un proceder deliberado, desaprensivo o sumamente imprudente.

Asimismo, para sustentar esta posición, mas sin acometer un ejercicio de derecho comparado, revisaré la fecunda experiencia que ofrecen los derechos norteamericano e inglés, en esta rama de la responsabilidad civil. En efecto, no obstante que estos sistemas representan el common law, tradición oficialmente tan disímil del Derecho Civil, de que es tributario el derecho chileno, ambos ordenamientos se constituyen en referentes que sería conveniente atender, si queremos dirimir la colisión entre la libertad de expresión de los Medios y la honra de las personas públicas, con mayor sofisticación y equidad que la que reflejan los más recientes pronunciamientos de nuestros tribunales ordinarios de justicia.

\footnotetext{
5 "Esta culpa en materias civiles equivale al dolo". Art. 44 inc. $2^{\circ}$ CC. Sobre la asimilación de la culpa lata al dolo en la responsabilidad contractual y extracontractual, véase BANFI (2003) y (2012).

6 "La Constitución asegura a todas las personas: 21․ El derecho a desarrollar cualquiera actividad económica que no sea contraria a la moral, al orden público o a la seguridad nacional, respetando las normas legales que la regulen". Art. $19 \mathrm{~N}^{\circ} 21$ inc. $1^{\circ}, \mathrm{CPR}$.
} 
Por ende, a pesar de las diferencias formales que distancian al sistema angloamericano del nuestro, ambas tradiciones enfrentan el mismo tipo de situaciones fácticas $y$, por eso, como enseña el método comparado funcional $^{7}$, resulta al menos sensato examinar aquel derecho que, por acumular un significativo acervo de conocimiento y experiencia en el tópico, puede iluminar al otro derecho que, en cambio, se halla en un estado de desarrollo más incipiente.

En suma, lo que este trabajo propone es que los daños que los Medios infligen negligentemente a quienes ocupan posiciones de poder político o administrativo, con motivo del desempeño de su actividad periodística, que es sin dudas riesgosa, están justificados por la relevancia económica, social y política de la libertad de informar en la sociedad.

Luego, la tensión entre la libertad de expresión de los Medios y el derecho a la honra de las personas públicas, sólo puede ser zanjada a favor de éstas, dando lugar a la responsabilidad civil, en la medida que se acredite un abuso particularmente calificado.

Este artículo se divide en cinco partes. La sección I aborda la actividad periodística en términos del riesgo jurídico y también sociológico que entraña, cuya materialización gatilla la responsabilidad civil. La sección II trata de la responsabilidad patrimonial de los Medios, respecto de las personas públicas en el derecho chileno actual, analizando críticamente la jurisprudencia reciente y argumentando que en estos casos, la libertad de informar opera como una causal de justificación del daño que inflige a dichas personas, a menos que se abuse gravemente de la misma, mediante la difusión de noticias falsas dolosamente o con completa desconsideración de la veracidad o falsedad de las mismas, conducta esta última que se asemeja estrechamente a la culpa lata que la ley asimila al dolo en toda materia civil. La sección III ahonda en la necesidad de limitar la responsabilidad civil de los Medios hacia las personas públicas, a abusos calificados del derecho a la libertad de expresión de que aquellos son titulares. Es esta forma extrema de abuso -consistente en la malicia o la indiferencia temeraria, equiparable a la culpa grave- la que se exige en el derecho angloamericano como condición para imputar la responsabilidad a los Medios que menoscaban la reputación de personas públicas involucradas en hechos de interés general, es decir, en el mismo tipo de situaciones que las que han enfrentado nuestros jueces. Fuera de estos casos límite de abuso, la lesión a la honra que puedan padecer las personas públicas a consecuencia de la comunicación negligente de noticias falsas pero que al tiempo de su divulgación eran verosímiles, es un efecto

7 Zweigert Y KÖtZ (1998), pp. 32-47; Michaels (2006), pp. 339-382. 
enteramente justificado y que nuestro sistema jurídico debiera permitir. A partir de lo anterior, en la sección IV esbozo una sugerencia y en la sección $\checkmark$ deslizo una conclusión.

\section{Riesgos del periodismo y responsabilidad civil}

\section{Riesgo y derecho privado}

El riesgo o peligro -en su sentido natural y obvio "la contingencia o proximidad de un daño o mal" ${ }^{8}$ - es, ante todo, una noción que informa distintos principios, instituciones y reglas del derecho público y privado.

La trascendencia del riesgo es patente en las instituciones más importantes del derecho privado: el contrato -instrumento de distribución de riesgos entre las partes, en especial el de incumplimiento y responsabilidad, limitada por la regla de previsibilidad (art. 1558) que suple la voluntad presunta de los contratantes $-{ }^{9}$, el seguro ${ }^{10}$, la compraventa ${ }^{11}$, el caso fortuito ${ }^{12}$, la teoría de los riesgos ${ }^{13}$, la teoría de la imprevisión ${ }^{14}$, los interdictos posesorios ${ }^{15}$ y, por cierto, la responsabilidad civil ${ }^{16}$.

\footnotetext{
${ }^{8}$ Diccionario de la Lengua Española, 22a ed. ("RAE") en relación al art. 20 CC. Éste no define peligro ni riesgo, pero, trasluciendo la riqueza idiomática de Bello, parece tratarlos como sinónimos: el peligro, en arts. 81 inc. $1^{\circ}, 113$ inc. $3^{\circ}, 226$ inc. $2^{\circ}, 406$ inc. $3^{\circ}, 466$ inc. $1^{\circ}, 604,935,1035,1046$ inc. $1^{\circ}$, 1053 inc. $1^{\circ}, 1260$ inc. $2^{\circ}, 1605$ inc. $1^{\circ}, 1826$ inc. $4^{\circ}, 1852$ inc. $3^{\circ}, 1996$ inc. $2^{\circ}, 2084$ inc. $1^{\circ}, 2288$ inc. $2^{\circ}$ y 2350 inc. $4^{\circ}$; y el riesgo, en arts. 155 inc. $4^{\circ}, 271 \mathrm{~N}^{\circ} 3,1550,1792-22,2116$ inc. $1^{\circ}$. Otros vocablos los especifican: acaso (art. 1477); acontecimiento (arts. 79, 1473, 1482); actos de autoridad, apresamiento y naufragio (arts. 45, 79, 604); avenida, rayo o terremoto (arts. 652, 908, 934); calamidad, ruina y saqueo (arts. 80, 932, 2003 regla 3a , 2236, 2323 y 2324); caso fortuito o fuerza mayor (art. 45 y una larga lista de ejemplos); contingencia (art. 1441); evento (arts. 739, 804, 1911); incertidumbre (arts. 130 inc. $1^{\circ}, 1599,1602,2152$ ); incierto (arts. 1070, 1081, 1083, 1086, 1911); indeterminado (arts. 1081, 1085, 1544), etc. FueYo (1953), Tomo I, p. 144, y Tomo II, p. 149.

${ }^{9}$ Claro (1979), pp. 661-663; Baraona (1998), pp. 198-199; Corral (2010), pp. 181 y 187.

${ }^{10}$ Arts. 513 y 1162 del Código de Comercio chileno. Baeza (2012), pp. 69-70; Ríos (2015), pp. 150-167.

11 Alessandri (2013), p. 589.

12 Art. 45. Coutasse e Iturra (1958), pp. 54 y 85; Brantt (2010), pp. 13-15, 107, 159-160; Tapia (2013), pp. 6-9 y 16-30.

${ }^{13}$ Matus (1955), pp. 13-14; Fueyo (1958), pp. 218-219; López (2010), pp. 510-511.

${ }^{14}$ De la Maza (1933), pp. 73-158; Fueyo (1954), pp. 89-108; Peñallillo (2000), pp. 209-237; Abeliuk (2010), pp. 840-848; LóPEZ (2010), pp. 248-273; MOMBeRG (2010), pp. 29-64.

15 Peñailillo (2006), pp. 545-560; Amunátegui (2009), pp. 505-525; Cárdenas (2016), pp. 285-299; TISNÉ (2017).

${ }^{16}$ Esteve (1999), p. 32.
} 


\section{Riesgo y responsabilidad civil}

La responsabilidad civil, institución que hace excepción al principio que ordena a cada cual asumir sus propios infortunios ${ }^{17}$, es eminentemente resarcitoria: reacciona ante un riesgo previsible y materializado -el daño ${ }^{18}$ - cuyo autor debió impedir con prescindencia de su dolo o negligencia (responsabilidad estricta) u observando el nivel de cuidado preestablecido en una norma -legal o reglamentaria- o determinado por el juez con posterioridad a los hechos, en el régimen común y supletorio de los arts. 2314 y siguientes ${ }^{19}$.

En concreto, la culpa implica la omisión de un deber de diligencia impuesto precisamente para prevenir la producción del riesgo ínsito en la actividad respectiva ${ }^{20}$.

Luego, pese a la tendencia a rechazar la responsabilidad civil por mera creación de riesgos ${ }^{21}$, el juez debe determinar si el daño dimanó de un riesgo que el derecho no tolera ${ }^{22}$.

Además, el carácter reactivo de la responsabilidad civil, como es la que surge del abuso del derecho a la libertad de expresión, se condice con la proscripción de la censura previa ${ }^{23}$.

17 "El principio general de nuestro derecho es que la pérdida por un accidente debe quedar donde caiga y este principio no se ve afectado por el hecho de que un ser humano sea el instrumento de la desgracia... un perjuicio resultante de un accidente inevitable, o, lo que de acuerdo al derecho o a la razón constituye la misma cosa, de un acto que el cuidado y la previsión humanos y ordinarios son incapaces de precaver, no es sino la desgracia del damnificado, sin que constituya fundamento para la responsabilidad": HOLmes (1964), p. 95.

${ }^{18}$ La responsabilidad civil y los torts adquieren trascendencia económico-social con la aparición del ferrocarril en Inglaterra. Esta nueva tecnología expandió el riesgo de accidentes a las personas y bienes, por los incendios iniciados por chispas provenientes de trenes a carbón: MARTíN-CASALS (2010), pp. 1-18.

${ }^{19}$ Alessandri (1943), pp. 28, 547 y 533; Gatica (1959), pp. 58-59; Díez (1997), p. 159; Domínguez (1990), p. 135; Barros (2006), p. 215; Tapia (2007), pp. 149-151; Domínguez (2010), pp. 671-685.

20 "[T]ales deberes legales no fueron cumplidos, puesto que resultó un hecho asentado en la causa... que las barreras de contención de la vía por la cual transitaba la víctima se encontraban en mal estado, sin la debida mantención y con desperfectos que tampoco se hallaban señalizados, de manera de prevenir la existencia de un riesgo a quienes transitaban por el lugar": Corte Suprema, rol № 58132017, 20 de septiembre de 2017, cons. 10.

${ }^{21}$ La exposición de un sujeto a un riesgo de sufrir un mal no comporta la lesión de un derecho suyo -esto es, un daño resarcible- que amerite restaurar la justicia correctiva: WeINRIB (1995), pp. 156-157.

22 Esteve (1999), pp. 37-38 y 56.

${ }^{23}$ La libertad de expresión "consiste en el derecho a expresarse sin censura previa, pero a condición de que se responda por las consecuencias del ejercicio de esta libertad. De este modo, la decisión de una persona a expresarse no debería ser controlada por la sociedad antes de que ella se materialice, pero sí podría serlo una vez materializada...se trataría de una facultad individual y autónoma, sujeta sí al denominado principio de responsabilidad": SierRA (1997), p. 19; "[La] Constitución contempla un sistema de responsabilidad ex post, o sea, cuya observancia se hace efectiva con ulterioridad al 
Sin embargo, como afirman el Law \& Economics y la dogmática civil, la naturaleza ex post de la responsabilidad civil no priva a las reglas indemnizatorias de su poder disuasivo ${ }^{24}$, ya se trate de la responsabilidad estricta ${ }^{25}$, ya de la responsabilidad por culpa.

De hecho, es usual que la norma o la sentencia judicial defina la negligencia según la magnitud y/o probabilidad del daño, factores intrínsecos al riesgo y que, entre nosotros, subyacen al art. $2329^{26}$.

\section{El periodismo: una actividad riesgosa que puede gatillar la responsabilidad civil}

El trabajo periodístico es fuente de riesgos que pueden devenir en daños resarcibles. En efecto, los perjuicios que los Medios irrogan a terceros ejerciendo su derecho a la libertad de expresión materializan el riesgo consustancial a su giro: la divulgación de información falsa susceptible de menoscabar la honra ajena.

La responsabilidad civil resultante de la concreción de dicho riesgo se sujeta al estatuto común ${ }^{27}$.

Además, según una interpretación a contrario sensu del texto del art. 2331, la responsabilidad abarcaría únicamente el daño emergente y el lucro cesante provenientes de imputaciones injuriosas contra la reputación ajena ${ }^{28}$. Es decir,

ejercicio de dichas libertades. Si se hubiese admitido el sistema preventivo, entonces tendríamos un régimen, siempre ilegítimo, por ser de censura previa. Esta última o ex ante, se halla prohibida": CEA (2012), p. 394; ANGUita (2005), pp. 60-61.

${ }^{24}$ LANDes y Posner (1987), pp. 9-12; Shavell (1987), pp. 5-32. "[L]a amenaza que se impone al agente de correr con los costos efectivos de los accidentes que provoque actúa como un incentivo perfecto para que adopte los niveles óptimos de prevención": BARROS (2006), p. 217. "[L]a responsabilidad civil no puede ser entendida como una cortapisa a la libertad de prensa, sino como un aliciente para que ella se ejerza de modo lícito y sin causar daños innecesarios a otro": CORRAL (2006), p. 256.

25 "La responsabilidad por culpa tiene un elemento objetivo que la aleja del reproche personal; pero esa objetividad es radicalizada en el caso de la responsabilidad estricta, porque ésta ni siquiera requiere que la conducta sea objetivamente reprochable. Lo determinante es que se materialice un riesgo que está bajo el control del responsable": Barros (2006), p. 445.

${ }^{26}$ Alessandri (1943), pp. 292-305; Ducci (1971), pp. 97-110; Barros (2006), pp. 107-112; Aedo (2014), pp. 705-728; BANFI et al. (2018), pp. 203-207.

27 Art. 40 inc. 1\%, Ley No 19.733, de 2001.

${ }^{28}$ El honor, a diferencia de la honra, "corresponde a la autoestima, a la consideración o, quién sabe, si a la vanidad o al orgullo que cada cual tiene de sí mismo": CeA (2012), p. 201. "El término honra tiene dos acepciones: a) subjetivo: es el aprecio que cada uno tiene de sí mismo, y b) objetivo: que es la reputación o buena fama que los terceros tienen de uno, amparando la Constitución este segundo aspecto, pues el primero queda en efecto en el fuero interno del sujeto; en cambio, el objetivo forma parte de la convivencia social y ésta es la que regula el Derecho, toda vez que constituye la proyección 
no se repararía el daño moral ${ }^{29}$, lo que es sin dudas absurdo dado que éste es el principal detrimento $-y$ con frecuencia el único- que padecen las víctimas de recriminaciones ofensivas o ultrajantes ${ }^{30}$.

Empero, la doctrina y jurisprudencia han circunscrito el art. 2331 a los agravios al honor u honra perpetrados por sujetos distintos a los Medios, señalando que éstos responden especialmente del daño moral ${ }^{31}$.

Es más, se sostiene que el resarcimiento del daño moral es congruente con la consagración constitucional del derecho al honor y a la honra -proyecciones de la dignidad e integridad personales ${ }^{32}-$ y con el principio de reparación

de la dignidad del ser humano": Corte de Apelaciones de Santiago, rol № 983-1993, 31 de mayo de 1993, cons. $7^{\circ}$.

29 "Pero ello no obsta a que la víctima pueda pedir otra reparación que no sea pecuniaria, como la publicación de la sentencia condenatoria o de un desmentido emanado del autor de la injuria o calumnia": AlesSANDRI (1943), p. 231. No existen antecedentes sobre las fuentes consideradas por Bello al redactar el art. 2331. Probablemente fue persuadido por la idea de raigambre romana, recogida en las Partidas y explicada por Bentham, de que la ofensa al honor es inapreciable e irreparable monetariamente: Domínguez (2011), p. 421; BARRIENTOS (2012), p. 1071. El Tribunal Constitucional ("TC") invoca este argumento al pronunciarse sobre la inconstitucionalidad del art. 2331: "Que el derecho a la honra, por su esencia espiritual y moral como emanación de la dignidad de la persona humana carente de materialidad, no posee en sí mismo valor económico o patrimonial, por lo que el resultado dañino de los atentados en su contra se traducirá, ordinariamente, en sufrimientos o mortificaciones de igual carácter, esto es, en daño moral, aunque eventualmente, en ciertos casos, pueda adquirir algún efecto económico susceptible de ser calificado de daño patrimonial". TC, rol № 943-2007, 10 de junio de 2008 , cons. $36^{\circ}$.

30 "Que el efecto natural de la aplicación del precepto legal impugnado en estos autos -artículo 2.331 del Código Civil- es, precisamente, privar a los atentados contra el derecho a la honra que no constituyan delitos específicos, de la protección de la ley, pues, mientras las lesiones a otros derechos igualmente no constitutivas de delitos dan lugar a indemnización por todos los daños patrimoniales y morales causados, de acuerdo a la regla general del artículo 2329 del Código Civil, las imputaciones injuriosas contra el honor o el crédito de una persona no dan derecho a la indemnización del daño moral, que es naturalmente el producido por esta clase de atentados y, ordinariamente, el único": TC, rol No 943-2007, 10 de junio de 2008, cons. 37º, y rol № 1185-2008, 19 de abril de 2009, cons. $17^{\circ}$.

31 Alessandri (1943), p. 230.

32 "[Q]ue el respeto y protección del derecho a la honra, que asegura la Constitución, es sinónimo de derecho al respeto y protección del "buen nombre" de una persona, derecho de carácter personalísimo que es expresión de la dignidad humana consagrada en su artículo $1^{\circ}$, que se vincula, también, con el derecho a la integridad psíquica de la persona, asegurado por el $N^{0} 1$ de su artículo 19, pues las consecuencias de su desconocimiento, atropello o violación, si bien pueden significar, en ocasiones, una pérdida o menoscabo de carácter patrimonial más o menos concreto (si se pone en duda o desconoce la honradez de un comerciante o de un banquero, por ejemplo), la generalidad de las veces generan más que nada una mortificación de carácter psíquico, un dolor espiritual, un menoscabo moral carente de significación económica mensurable objetivamente, que, en concepto del que lo padece, no podría ser reemplazada o compensada con una suma de dinero": TC, rol № 943-2007, 10 de junio de 2008 , cons. $27^{\circ}$. 
integral ${ }^{33}$. Por eso, desde esta perspectiva, también es cuestionable la lectura exegética del art. 2331 que veda la compensación del daño moral resultante de denuncias afrentosas proferidas sin publicidad ${ }^{34}$.

Curiosamente, aunque la norma aludida parece haber sido derogada tácitamente por la CPR o al menos caído en desuso ${ }^{35}$, el TC no la declaró inconstitucional $^{36}$. Sólo ha descartado aplicarla en decenas de juicios concretos ${ }^{37}$.

Así, la reforma legal del art. 2331 parece la ruta más segura ${ }^{38}$, como intentó un grupo de diputados mediante un proyecto de ley que, cabe lamentar, desde septiembre de 2013 duerme en la Cámara (el "Proyecto") ${ }^{39}$.

El Proyecto pretende responsabilizar a los Medios de los daños materiales y morales causados a terceros, sin perjuicio de la responsabilidad penal por los delitos de injuria o calumnia en que puedan incurrir sus directores.

Adicionalmente, el Proyecto intenta dar un trato distinto a los casos en que concurren causales que justifican la lesión a la honra y/o privacidad, como sucede cuando existen hechos de interés público, para "evitar que se produzca la simple derogación de la norma con resultados poco satisfactorios para la armonía del ordenamiento jurídico y con riesgos para la libertad de expresión y de prensa" ${ }^{40}$.

Por otra parte, la ambigua redacción del art. 40 de la Ley № 19.733 de 2001 -precepto que parece supeditar la responsabilidad civil de los Medios

\footnotetext{
33 Domínguez (2010), pp. 671-685; Domínguez (2011), pp. 418-421.

34 DíEZ (1997), p. 125.

35 Tapia (2005), p. 94; Barros (2006), p. 579, criterio acogido recientemente: Larraín (2011), pp. 143-189.

${ }^{36}$ TC, rol No 1723-2010, 24 de mayo de 2011.

${ }_{37}$ Por ejemplo, TC rol № 943-2007, 10 de junio de 2008; rol № 1185-2008, 19 de abril de 2009; rol No 1463, 23 de septiembre de 2010; rol № 1679-2010, 15 de marzo de 2011; rol № 2071-2011, 19 de junio de 2012; rol № 2410-2013, 29 de agosto de 2013; rol № 2747-2014, 25 de agosto de 2015; rol No 2860-2015, 26 de enero de 2016; rol № 2915-2015, 19 de mayo de 2017.

${ }^{38}$ Corral (2013), pp. 280 y 381-382.

${ }^{39}$ El nuevo texto dispone: "Art. 2331. Las imputaciones contrarias a la honra o los atentados contra la vida privada o la imagen de la persona darán derecho a la reparación de todos los daños sean materiales o morales. // No obstante, la acción para exigir reparación de los daños causados a la honra, la vida privada o la imagen por un medio de comunicación social se regirá por lo previsto en la ley especial de libertades de opinión e información y ejercicio del periodismo".
}

${ }^{40}$ Exposición de motivos del Proyecto. 
a una condena penal por calumnia o injuria ${ }^{41}-$ ha suscitado vacilaciones jurisprudenciales ${ }^{42}$.

La doctrina, en cambio, acepta la reparación de los daños materiales y morales que los Medios infligen a terceros independientemente de la responsabilidad penal que pueda afectar a sus representantes ${ }^{43}$.

Sin embargo, este criterio dogmático es compartido por la jurisprudencia más reciente. Así, se ha declarado que el art. 2331, como excepción que hace al principio de reparación integral ${ }^{44}$, debe ser interpretado restrictivamente; que los arts. 1556 y 2331 no aluden al daño moral, pues Bello no lo consideró y, por ende, no pudo querer excluirlo ${ }^{45}$; y que la acción civil es autónoma de la acción penal, de suerte que los Medios responden de todos los perjuicios ocasionados a terceros, en particular del daño moral (arts. 2314 y 2329) ${ }^{46}$.

41 "La acción civil para obtener la indemnización de daños y perjuicios derivada de delitos penados en esta ley se regirá por las reglas generales. // La comisión de los delitos de injuria y calumnia a que se refiere el artículo 29 [en relación a los arts. 413, 418 inc. $1^{\circ}$ y 419 del Código Penal, 'CP'], dará derecho a indemnización por el daño emergente, el lucro cesante y el daño moral".

42 "[P]ara que proceda la indemnización de perjuicios establecida en el segundo de los preceptos antes citados [art. 40 Ley $\mathrm{N}^{\circ} 19.733$ de 2001], se requiere...[sic] se encuentre acreditado previamente la existencia de la comisión de los delitos de injuria y calumnia, lo que debe encontrarse resuelto por sentencia firme": $1^{\text {er } J u z g a d o ~ C i v i l ~ d e ~ S a n t i a g o, ~ r o l ~ N o ~ 9270-2010, ~} 20$ de marzo de 2013, cons. $23^{\circ}$.

43 Alessandri (1943), p. 230; CORRAl (2006), pp. 262-263.

44 "En lo que atinge a la improcedencia de la indemnización del daño moral, fundada en el artículo 2331 del Código Civil, dicha norma -de dudosa constitucionalidad-se refiere únicamente a las imputaciones injuriosas contra el honor y el crédito de una persona; sin embargo, dado su carácter - que hace excepción a la regla general del artículo 2329- debe ser interpretada en forma restrictiva, como muy bien se señala en la contestación de la demanda; ergo, no cabe aquí una interpretación por analogía, que la haga extensiva al delito de calumnia -penal o civil como en el caso subjudiceque la Corte ha tenido por establecido": Corte de Apelaciones de Antofagasta, rol № 159-2015, 30 de noviembre de 2015, cons. $13^{\circ}$.

45 "Por lo tanto, el artículo 2331 no debe ser leído en el sentido de la exclusión del daño moral, ya que el hecho de que la norma no lo mencione como tal daño, se debe a que a la época del Código no se tuvo en mente este tipo específico de daño, de suerte que en honor a la verdad nunca fue excluido, sino más bien no fue incluido expresamente y ello, simplemente, porque no fue considerado. Ahondando, la regla del artículo 2331 no formó parte de los códigos que sirvieron de fuente al nuestro. Y es la preceptiva constitucional y legal la que, en conjunto, permite entender que no existe razón valedera para excluir esta forma de daño que, sin duda, tiene un carácter y naturaleza distintos, pero que es la manera de dejar indemne un perjuicio cuyo campo de afectación es extrapatrimonial": Corte de Apelaciones de Santiago, rol № 4213-2011, 23 de noviembre de 2012.

46 "[Q]ue el artículo 66 del Código Procesal Penal permite el ejercicio previo de la acción civil, sin distinguir ante qué tribunal... los artículos 2314 y siguientes del Código Civil, refieren respecto de la responsabilidad extracontractual, delictual o aquiliana derivada de un hecho culpable o negligente que cause un resultado dañoso, que ha de ser distinto de un delito penal, desde que la acción indemnizatoria de un ilícito penal, se tramita de conformidad a las normas de la acción civil indemnizatoria que 
Análogamente, el TC considera que el art. 40 de la Ley № 19.733 de 2001, tiene aplicación sólo si se demandan los daños materiales y morales derivados de los delitos de calumnia e injuria. En contraste, la acción de perjuicios interpuesta contra los Medios se somete a las reglas generales, con la salvedad del art. $2331^{47}$.

\section{Un enfoque complementario del riesgo}

El riesgo es un fenómeno que trasciende al derecho. El riesgo ha sido, es y continuará siendo objeto obligado de análisis por parte de las ciencias exactas y sociales.

En concreto, los aportes de la sociología pueden ayudar a mejorar nuestra comprensión del riesgo en la responsabilidad civil en general y por la actividad periodística en particular.

Ante todo, porque el riesgo, a diferencia del peligro, no proviene de fenómenos naturales sino que de decisiones humanas ${ }^{48}$.

En efecto, como expresa Anthony Giddens, la idea de riesgo surgió cuando la humanidad se percató que "los resultados impredecibles pueden ser una consecuencia de nuestras propias actividades o decisiones, en lugar de expresar significados ocultos de la naturaleza o intenciones inefables de la Deidad". Es decir, "el riesgo reemplaza lo que antes se concibió como fortuna" 49.

Además, acota Giddens, vivimos en una sociedad postmoderna del riesgo global o mundial, la que se caracteriza no sólo por la vertiginosidad y extensión de las transformaciones, sino por la creación de instituciones sin precedentes históricos, como la Nación-Estado ${ }^{50}$.

Pues bien, como sostuviera Ulrich Beck, existe una diferencia fundamental entre las instituciones de la sociedad industrial y aquellas instauradas en la era postmoderna. Las primeras son creadas para atenuar la desigual distribución de la riqueza entre las capas o estamentos sociales. Las segundas, en contraste, propenden a mejorar la distribución no de los recursos económicos sino de

prevé el Código Procesal Penal": Corte de Apelaciones de Santiago, rol № 4078-2015, 21 de agosto de 2015 , cons. $7^{\circ}-8^{\circ}$.

47 TC, rol N ${ }^{\circ} 1185-2008,19$ de abril de 2009, cons. $19^{\circ}-23^{\circ}$.

${ }^{48}$ Esteve (1999), pp. 8-9 y 29; Rojas (2014), pp. 552-553. No obstante ello, "el peligro existe en circunstancias de riesgo y en efecto es relevante para definir en qué consiste éste...los riesgos que implica cruzar el Atlántico en una embarcación pequeña son considerablemente mayores a los que acarrea la travesía en un transatlántico dada la variación del elemento peligro involucrado": GIDDENS (1990), pp. 32-33. Ésta y las demás traducciones contenidas en este artículo son de su autor.

${ }^{49}$ Giddens (1990), pp. 30-31.

${ }^{50}$ GidDENS (1990), p. 6. 
lo riesgos, siendo su meta la seguridad. Con todo, fácil es percibir que ambas aspiraciones -igualdad y seguridad-son análogamente utópicas ${ }^{51}$.

El riesgo, advierte Beck, está estrechamente ligado a la idea de responsabilidad. Mas, para entender la responsabilidad que asumen las autoridades políticas y administrativas, incluyendo los órganos jurisdiccionales, respecto de la concreción de los riesgos que amenazan a las sociedades contemporáneas, es menester tener en cuenta que muchos de estos riesgos tienen un alcance del todo diferente de los que aquejaron al mundo industrial ${ }^{52}$.

En primer lugar, los riesgos actuales conciernen a daños catastróficos, irreversibles, universales e incontrolables, como son los que acarrearía un accidente o conflagración nuclear para la vida y la salud de las personas, aparte del desastre ambiental que desencadenaría simultáneamente.

En segundo lugar, la incertidumbre científica que ha predominado en la sociedad postmoderna desde los albores del siglo XX, torna prácticamente imposible calcular la probabilidad de que uno de dichos riesgos se materialice. Es lo que ocurre con el riesgo de contraer enfermedades cancerígenas a raíz de la exposición prolongada a sustancias liberadas en el aire que se respira en el lugar de trabajo. En efecto, la inocuidad o toxicidad de tales componentes es arduamente debatida entre los científicos según qué posición de la industria defiendan.

Una demostración palmaria del estado de incerteza prevaleciente en la cultura contemporánea es la sistemática exclusión de cobertura de los nuevos riesgos, tecnológicos u otros, en las pólizas de seguro que se comercializan en el mercado ${ }^{53}$.

\section{Falencias de la responsabilidad civil}

Las apreciaciones jurídicas y sociológicas precedentes nos recuerdan que la responsabilidad civil es, como toda institución humana, un instrumento imperfecto.

Por de pronto, la responsabilidad civil no contribuye mayormente a prevenir que se concreten no sólo los nuevos riesgos transfronterizos, respecto de los cuales la ciencia carece de respuestas unívocas, sino también las contingencias que corrientemente se ciernen sobre nosotros.

Pero el asunto es más serio. La ineficiencia de la responsabilidad civil igualmente afecta su rol esencial de reparar los daños en que tales riesgos se

\footnotetext{
${ }^{51}$ ВеСк (1998), pp. 55-56.

52 BeCK (1998), pp. 16-19 у (1999), pp. 5 у 9.

53 BeCK (1999), p. 87.
} 
convierten. En efecto, el indispensable nexo causal en no pocas ocasiones se erige en un obstáculo que impide identificar a los agentes creadores del riesgo que se tradujo en un daño ${ }^{54}$.

Luego, parecería ser que esta institución de derecho privado, que tanta importancia ha tenido en la época industrial, no es un medio adecuado para acometer los riesgos posmodernos ${ }^{55}$.

En realidad, la responsabilidad civil también refleja la insuficiencia del derecho privado ante riesgos más conocidos, como el que conlleva el ejercicio del derecho a la libertad de informar, piedra angular de la democracia, y que es el de lesionar la honra y/o privacidad de terceros ${ }^{56}$.

\section{Responsabilidad patrimonial de los Medios respecto de las personas públicas en el derecho chileno vigente}

\section{La libertad de expresión como causal de justificación que excluye la responsabilidad penal}

Del valor preeminente de la libertad de información en una sociedad democrática se sigue que la materialización del riesgo intrínseco a su ejercicio no puede generar sin más la responsabilidad de los Medios, a pesar de que conculquen el derecho a la honra de terceros ${ }^{57}$.

Esta aseveración es evidente, ante todo, en la responsabilidad penal. Ésta se subordina a la perpetración de los delitos de calumnia e injuria ${ }^{58}$.

Además, quien comete estos ilícitos a través de los Medios, queda exento de sanción si en el proceso acredita la veracidad de la imputación ${ }^{59}$ dirigida contra un funcionario público en relación a hechos propios de la labor de éste,

54 "Bajo el techo de los riesgos de la modernización se produce más tarde o más temprano la unidad del culpable y de la víctima... El smog no toma en consideración el principio de causación. Globalizando e igualando, afecta a todos, con independencia de la participación en su producción": BЕСk (1999), p. 45.

55 "Los desafíos de la era de la tecnología nuclear, genética y química se manipulan con conceptos y recetas derivadas de la primera sociedad industrial del siglo XIX y comienzos del siglo XX": BECK (1999), p. 87.

56 "[L]a información de los ciudadanos sobre todos los asuntos de interés público, o más exactamente, de todos los asuntos de relevancia pública, es un presupuesto necesario del correcto funcionamiento del sistema republicano democrático y de los mecanismos de responsabilidad política de las autoridades inherentes a dicho régimen político": Nogueira (2002), p. 28.

57 "El nivel de ejercicio seguro que en una Sociedad Civil tenga tal libertad [de expresión]... se considera, sin disidencia, un indicador claro de democracia efectiva del cual se goza en un país": CeA (2012), p. 382.

${ }^{58}$ Arts. 19 No 12, CPR; 413, 418 inc. $1^{\circ}$ y 419, CP; y 29, Ley No 19.733, de 2001, aparte del delito de intromisión indebida en la vida privada, tipificado en art. 39 de esta ley y en arts. 161-A y 161-B, CP. 59 "Cualidad de veraz", esto es, "que dice, usa o profesa siempre la verdad". Diccionario RAE. 
especialmente si el imputado defendió un interés público ${ }^{60}$, como es el que se promueve "en el ejercicio de una profesión u oficio [como el periodismo] y cuyo conocimiento tenga interés público real"61.

Por esta razón, se ha resuelto que no cometen el delito tipificado en el art. 161-A CP unos periodistas que, simulando ser pacientes, obtuvieron licencias falsas de psiquiatras para luego transmitir un reportaje por televisión. En efecto, la privacidad de las conversaciones "desaparece cuando se trata de conductas que revisten un interés público" e "importa al menos una transgresión a la ética por parte de profesionales de la salud que otorgaban licencias médicas falsas en desmedro de los demás cotizantes de los sistemas de salud, cuestión que reviste un interés público con mérito suficiente para ser socializada lo que permitirá en último término, el fin de una situación reprobable e inconveniente" ${ }^{\prime \prime 2}$.

Es decir, para eximirse de responsabilidad penal el imputado debe probar que corroboró la verosimilitud de lo informado y que para ello observó el grado de diligencia debido ${ }^{63}$.

No es necesario que el imputado demuestre la verdad absoluta de los hechos difundidos. En efecto, como explica la doctrina autorizada, "si se exigiera la veracidad objetiva, sólo se podrían transmitir en forma justificada informaciones pasadas por autoridad de cosa juzgada, y aun en tales circunstancias podría tratarse de informaciones erróneas, como lo reconoce la existencia del recurso de revisión, tanto en materias civiles como criminales" ${ }^{64}$. En idéntico sentido, se ha declarado que los delitos de calumnia e injurias graves "exigen que el sujeto activo, en sus intervenciones, tenga conciencia de la falsedad de los hechos que atribuye, sin perjuicio de que esos hechos, objetivamente considerados, pudieran ser verdaderos. Como principio general, aquel que atribuye públicamente por razones de interés social un hecho que razonablemente cree cierto, no incurre en delito, aunque esté equivocado, porque su creencia en la verdad de lo que sostiene excluye el dolo inherente a estas figuras penales" ${ }^{\prime 65}$.

\footnotetext{
${ }^{60}$ Art. 30 inc. $1^{\circ}$, Ley $N^{\circ} 19.733$, de 2001.

${ }^{61}$ Art. 30 inc. $3^{\circ}$, letra b), Ley $N^{\circ} 19.733$, de 2001. Con todo, el comprobar cualquiera de las hipótesis reguladas en las letras a) y b) de esta norma, es una tarea particularmente compleja: Politoff et al. (2009), p. 659.

${ }^{62}$ Corte Suprema, rol No 8393-2012, 21 de agosto de 2013, cons. 5. En cambio, la excepción de veracidad que admite el art. 420 CP es más limitada: sólo puede aducirse por el delito de injurias perpetrado en contra de empleados públicos sobre hechos atingentes al ejercicio de su cargo.

63 "Cualidad de verosímil", es decir, "que tiene apariencia de verdadero" o que es "creíble por no tener carácter alguno de falsedad". Diccionario RAE.

${ }^{64}$ Politoff et al. (2009), p. 645.

${ }^{65}$ Corte Suprema, rol No $1586-1999,5$ de julio de 1999, cons. $4^{\circ}$.
} 
En suma, la ley antepone el interés general de la sociedad al interés individual representado por el derecho a la honra ${ }^{66}$.

Esto significa que el derecho constitucional a la libertad de informar configura una auténtica causal que justifica la lesión a la reputación ajena, salvo que quien desarrolle este giro perpetre uno o más de los tipos penales citados, cuyo objeto es proteger dicho bien jurídico ${ }^{67}$.

\section{El derecho a la libertad de expresión como causal de justificación del daño a la reputación}

El menoscabo que pueda irrogarse a la honra de personas públicas mediante la difusión de noticias verosímiles sobre hechos de interés social, que en definitiva resultan ser falsas, es un efecto colateral que el sistema jurídico acepta en consideración al valor primordial que la libertad de expresión adquiere en situaciones que involucran a esas personas y respecto de tales sucesos. Es decir, la libertad de expresión desplaza a la reputación -y a la privacidad- de personas públicas involucradas en hechos de interés social ${ }^{68}$.

Luego, la libertad de informar acerca de circunstancias que atingen al "funcionamiento recto, probo y transparente de las instituciones y del Estado de Derecho", cuya divulgación el sistema jurídico no sólo autoriza sino alienta, -ya que "es legítimo revelar cuestiones que, si bien serían irrelevantes en una persona particular, no lo son cuando se trata de alguien que ocupa un cargo de representación o de servicio en interés de la sociedad"69-, impide calificar el ejercicio de la libertad como un comportamiento antijurídico y culpable, aun si vulnera la honra de personas públicas.

Por tanto, el mal que la actividad periodística pueda eventualmente infligir al prestigio de una persona pública, en principio no es un daño resarcible sino un efecto colateral justificado por el ordenamiento jurídico. La justificación reside en el ejercicio del derecho a la libertad de expresión de que son titulares los Medios y que prima sobre el derecho a la honra de las personas públicas.

${ }^{66}$ Grisolía (2004), p. 38; Garay y González (2008), pp. 245-246.

67 "Están exentos de responsabilidad criminal: $10^{\circ} \mathrm{El}$ que obra en cumplimiento de un deber o en el ejercicio legítimo de un derecho, autoridad, oficio o cargo". Art. 10 № 10, CP.

68 Nogueira (2002), pp. 164-171. En este sentido, se ha resuelto que "[L]a doctrina nacional acepta ampliamente que la expectativa de privacidad queda subyugada [ante la libertad de expresión] cuando se trata de una persona pública o de una conducta reprochable penalmente, y esta Corte, en fallos anteriores, ha reconocido la relevancia del concepto de información de interés público como justificante de la intromisión". Corte Suprema, rol No 38159-2016, 11 de agosto de 2016, cons. 11․

${ }^{69}$ Ambas frases recogidas de CORRAL (2006), pp. 266-267. 
Por ende, el efecto colateral aludido únicamente podrá ser tenido como perjuicio indemnizable si proviene del ejercicio abusivo del derecho a la libertad de informar. Sólo entonces la conducta en cuestión podrá ser calificada como antijurídica y culpable.

\section{La responsabilidad civil de los Medios sólo surge del abuso de su derecho a la libertad de informar y éste, según la doctrina mayoritaria, consiste en un acto meramente negligente}

De lo dicho se sigue que la responsabilidad por los daños que los Medios causen a terceros supone que aquellos abusen de su derecho a la libertad de informar. En efecto, "[e]/ principio fundamental que inspira la normativa constitucional y legal es reconocer la libertad para informar y opinar sin censura previa, pero respondiendo de 'delitos y abusos' cometidos en dicho ejercicio" ${ }^{\prime 70}$.

Vale decir, el abuso del derecho a la libertad de expresión es una condición esencial para atribuir responsabilidad civil a los Medios que lesionan la honra de personas públicas.

En general, los Medios responden de los daños que ocasionen a los terceros a consecuencia de su omisión dolosa o culpable en cerciorarse acerca de la veracidad de lo informado ${ }^{71}$.

Pero el estándar de cuidado exigible a los Medios no impone que éstos comprueben la verdad científica e incuestionable de los hechos que pretenden comunicar. Tal requisito coartaría su libertad de informar e implicaría una responsabilidad estricta encubierta, lo que "tendría un efecto silenciador para la divulgación de información que los ciudadanos deben tener disponible lo antes posible en una sociedad democrática" ${ }^{\prime 72}$.

Por el contrario, el deber de los Medios es más modesto: sólo deben "efectuar una razonable comprobación de la información, chequearla, corroborarla, contrastarla entre las distintas fuentes de información a las cuales se haya accedido al momento de redactar columnas, reportajes o artículos de opinión e información" ${ }^{\prime 73}$.

\footnotetext{
${ }^{70}$ Corral (2013), p. 279.

${ }^{71}$ Barros (2006), pp. 581-582.

72 PINO (2014), pp. 263-264.

${ }^{73}$ Anguita (2005), pp. 24-25. Los Medios tienen que cumplir "una suerte de deber de cuidado en el chequeo de las fuentes, lo que será medido conforme a la velocidad de funcionamiento de los Medios pero también en directa proporción con la gravedad de la imputación": CORRAL (2006), p. 271.
} 
De lo que se trata, entonces, es que la información publicada por los Medios supere el umbral de verosimilitud aunque después se constate un yerro. Éste no equivale ni entraña descuido ${ }^{74}$.

Ahora, para determinar el ámbito y los límites de la libertad de expresión, la doctrina nacional distingue los casos en que los Medios lesionan la honra de quienes desempeñan funciones públicas de aquellas situaciones que afectan a personas que carecen de esas calidades. La doctrina discrimina también los casos que concitan un interés social de aquellos que no.

Sin embargo, este tratamiento diferenciado no cubre el factor de imputación subjetivo. En efecto, según la tesis dominante, la mera imprudencia es suficiente para imputar responsabilidad civil, incluso en situaciones calificadas por la clase de personas implicadas ${ }^{75}$.

Luego, si bien el ámbito de protección del honor de una persona privada es más extenso que el de una persona que cumple funciones públicas, el simple descuido permite atribuir responsabilidad en ambos eventos. En palabras de Arturo Alessandri Rodríguez: "[L]a actuación pública de las personas y de las corporaciones, aunque no desempeñen funciones públicas, al igual que la de todos aquellos que por los cargos que sirven o por las actividades a que se dedican están expuestos a la crítica general, como la actuación política de un político... la labor o conducta de un funcionario o empleado público... puede ser objeto de críticas y comentarios hechos con publicidad: si son mesurados y respetuosos y a base de hechos exactos, no imponen responsabilidad a su autor por severos que sean. Pero si son maliciosos, injuriosos o calculados para desprestigiar a la persona o corporación contra quien van dirigidos o se formulan con ligereza o negligencia, son abusivos y obligan a reparar el daño que causen" ${ }^{76}$.

En consecuencia, de acuerdo a esta interpretación, el término "abusos" que utiliza el art. $19 \mathrm{~N}^{\circ} 12$ de la CPR abarcaría tanto el delito como el cuasidelito civil 77 .

\footnotetext{
${ }^{74}$ Nogueira (2002), pp. 29-32.

75 Alessandri (1943), p. 230.

76 Alessandri (1943), pp. 286-287.

77 Nogueira (2002), p. 31; Corral (2006), p. 274, № 22, desestimando New York Times v. Sullivan. En este célebre caso, un comisionado de la policía de Montgomery, Alabama, demandó daños compensatorios y punitivos al periódico neoyorkino derivados de la publicación en la edición del 29 de marzo de 1960, a página completa, de un aviso en que se pedían contribuciones para el "Comité en defensa de Martin Luther King y por la lucha de la libertad en el Sur", comentario editorial sobre el maltrato dado por las fuerzas policiales de dicha localidad a Dr. King y estudiantes negros que reclamaban sus derechos civiles. El periódico fue condenado, según el veredicto del jurado, a pagar al actor US\$ 500.000 a título de daños, sin distinguirse los compensatorios de los punitivos. El fallo, confirmado
} 
Esta aproximación concuerda, por lo demás, con la noción convencional de abuso del derecho, a saber: un comportamiento anormal que excede el umbral de molestias tolerables entre miembros de la comunidad en un contexto dado ${ }^{78}$.

\section{El estado de la cuestión en la jurisprudencia}

En reiteradas oportunidades los jueces civiles chilenos han zanjado conflictos entre la reputación de una persona y la libertad de informar de los Medios.

Con todo, en las escasas sentencias recaídas en litigios por daños a la honra de personas públicas no se advierte una aplicación de las reglas de responsabilidad civil suficientemente diferenciada respecto de los casos que afectan el crédito de personas comunes y corrientes ${ }^{79}$.

Por el contrario, los Medios han sido condenados a resarcir los daños patrimoniales y morales supuestamente causados a personas públicas en virtud de fallos que no evidencian una comprensión del singular problema envuelto en este tipo de pleitos.

A su vez, la jurisprudencia tiende a proteger la reputación del ciudadano de a pie frente a la libertad de expresión de los Medios, ordenándoles indemnizar los daños causados al divulgar imprudentemente información falsa.

Una breve mención de algunas sentencias recientes servirá para ilustrar la diferencia entre esta especie de conflictos de aquellos que conciernen a personas públicas.

en segunda instancia, fue revocado por la Corte Suprema, pues no se probó que el demandado publicó una noticia falsa a sabiendas o con imprudencia temeraria hacia su verosimilitud o falsedad (malicia real), estándar de responsabilidad civil de los Medios para con funcionarios públicos en ejercicio de sus atribuciones. KALVEN (1964), pp. 194-195.

78 Alessandri (1943), pp. 261 y 285-288; Barros (2006), pp. 626-635 y 649-650; Viney (1995), pp. 351 352; Mazeaud et al. (1998), p. 477; Carbonnier (2000), § 167; Gómez (2006); Bercovitz (2009), pp. 1-4.

${ }^{79} \mathrm{~A}$ estos casos se suman las acciones de daños interpuestas por personas famosas en el mundo profesional, político, artístico, deportivo, etc., en contra de los Medios. Las particularidades que brinda este grupo de casos justifica un examen autónomo que excede el propósito del presente artículo. Sólo citaré, a modo ilustrativo, Corte Suprema, rol № 5844-2013, 19 de marzo de 2014: periodistas de la demandada, fingiendo enfermedades psiquiátricas, pidieron a la actora les extendiera licencias médicas. La conversación fue grabada mediante cámaras ocultas y transmitida por televisión en un programa que denunció supuestos fraudes en el sistema privado de salud, acusando a la actora de lucrar mediante la entrega de licencias médicas falsas. La actora demandó la indemnización del daño moral lo que fue aceptado en ambas instancias. La Corte Suprema casó el fallo de alzada por infringir normas reguladoras de la prueba pues dio por acreditado el daño moral sin mayores antecedentes. En su voto de minoría, el Ministro Sr. Blanco declaró que la demandante sufrió una lesión a su reputación al ser tratada públicamente como autora de un delito que no fue establecido por sentencia firme. 


\subsection{Responsabilidad de los Medios respecto del común de las personas}

Por un lado, existe un volumen significativo de juicios dirigidos contra canales de televisión, entre los que sobresalen tres fallos que declararon que dichos Medios:

i) No responden de los daños patrimoniales y morales alegados por personas naturales y jurídicas a consecuencia de la transmisión de un reportaje periodístico que les imputó el hecho, probado en el proceso, de vender en el mercado nacional un licor como si fuera el producto alcohólico auténtico, utilizando una etiqueta muy similar a éste, en circunstancias que era importado y comercializado por el codemandado ${ }^{80}$;

ii) Deben resarcir el daño moral irrogado a la residente de un condominio al transmitir de modo parcial y descontextualizado la entrevista efectuada a la misma, haciéndola aparecer como prejuiciosa y clasista, lo que desencadenó airadas reacciones de animosidad en las redes sociales ${ }^{81}, y$

iii) No responden de los daños reclamados por el fabricante de materias primas usadas en la manufacturación de alimentos si, antes de salir el programa al aire, el canal de televisión corroboró que la actora infringió normas sanitarias, lo que motivó la instrucción de un sumario por la autoridad sanitaria, pues así el demandado demostró que se ciñó al estándar de diligencia y que actuó de buena fe ${ }^{82}$.

Por otro lado, la prensa también ha debido indemnizar perjuicios sufridos por particulares, como el daño moral derivado de la lesión de la privacidad y honra de una mujer violada, cuya identidad fue dada a conocer en la noticia publicada por el periódico demandado, lo que fue calificado de imprudente y causante del daño ${ }^{83}$.

Igualmente debe reparar el daño moral ocasionado a un taxista el diario que lo sindicó, incluyendo una fotografía de aquél, como autor de presuntos delitos de violación y abusos deshonestos de menores de edad, en circunstancias que el actor sólo tenía la calidad de imputado y al poco tiempo fue absuelto por sentencia firme ${ }^{84}$.

En cambio, no es civilmente responsable el periódico que inserta un reportaje que, reproduciendo las palabras del entrevistado, indica que el demandante lo estafó pues no ejecutó las obras de construcción comprometidas. En efecto, se estimó que los epítetos coloquiales vertidos en la nota periodística no podían configurar un delito o cuasidelito civil ${ }^{85}$.

\footnotetext{
${ }^{80} 2^{\circ}$ Juzgado Civil de Santiago, rol No 28073-2007, 28 de enero de 2011.

${ }^{81}$ Corte de Apelaciones de Santiago, rol № 4078-2015, 21 de agosto de 2015 (confirmando $28^{\circ}$ Juzgado Civil de Santiago, rol No 10926-2012, 28 de enero de 2015).

${ }^{82}$ Corte Suprema, rol № 6897-2017, 3 de agosto de 2017.

${ }^{83}$ Corte de Apelaciones de Santiago, rol № 6597-2014, 12 de marzo de 2015.

${ }^{84}$ Corte de Apelaciones de La Serena, rol No 600-2014, 31 de julio de 2015.

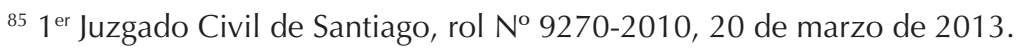




\subsection{Responsabilidad de los Medios respecto de personas públicas}

Sin embargo, mi interés está puesto en dos recientes sentencias que, habiendo acogido la acción de perjuicios entablada por una persona pública en contra de dos periódicos de circulación nacional, no distinguieron con suficiente claridad esta categoría de los otros grupos de casos antes reseñados ${ }^{86}$.

Ambos litigios nacen de unos mismos hechos, a saber: en la noche del lunes 30 de junio de 2008, el Director de Seguridad y Orden Público de Carabineros, General Sr. Samuel Cabezas, convocó de urgencia a una conferencia en la que comunicó a la prensa que la institución había dispuesto la salida inmediata de don Juan Ignacio Loyola Villalobos ("Loyola"), a la sazón Teniente Coronel de Carabineros, pues durante pesquisas realizadas a la banda de narcotraficantes "Carejarro", la Policía de Investigaciones interceptó conversaciones telefónicas entre Loyola y el abogado Ariel Marín, supuestamente miembro de esa organización criminal. Entre los días 30 de junio y 3 de julio de 2008 diversos Medios informaron que Carabineros había expulsado a Loyola por sus nexos con narcotraficantes ${ }^{87}$.

El Diario La Cuarta ("La Cuarta") publicó en su portada del martes 1 de julio de 2008 el titular "Comandante de Carabineros se fue de PLR por vínculos con 'Los Carejarro'". El reportaje, en página 3 del matutino, expresaba: "Carabineros expulsó al comandante Juan Loyola debido a sus relaciones con Ariel Marín,

${ }^{86}$ Corte de Apelaciones de Santiago, rol No 438-2015, 15 de abril de 2015; y Corte Suprema, rol № 65403-2016, 13 de junio de 2017. Excluyo de este análisis los juicios sobre el daño moral experimentado por personas públicas a raíz de la intrusión de los Medios en la intimidad o privacidad de aquellos que no repercuten en el desempeño de sus funciones, como Calvo con Red de Televisión Chilevisión S.A. (2015), donde el bien jurídico conculcado fue la privacidad de la víctima directa -el Juez Daniel Calvo-y de las víctimas indirectas -su cónyuge e hijos- luego que trabajadores de la demandada grabaron subrepticiamente al magistrado en su despacho privado en el Palacio de los Tribunales de Justicia. Los jueces del fondo y la Corte Suprema declararon que la responsabilidad de la demandada por el daño moral infligido a los actores emanó del delito de intrusión tipificado en el art. 161-A inc. $1^{\circ}$ CP Barros (2006), p. 553 № 52; Corral (2006), pp. 268-269. A propósito de este caso, se indica que "La orientación sexual de un funcionario no tiene por qué ser de incumbencia del público y se puede suponer que no afecta el desempeño de su cargo. Sin embargo, existe en Chile cierta noción de que los funcionarios públicos, incluidos los jueces, no deben concurrir a prostíbulos gays. Así, una intromisión en la vida privada del juez en relación con ese asunto se podría justificar para verificar si la persona en su vida privada se ajustaba al estereotipo de juez imperante en Chile. Con todo, el caso del juez Calvo es complejo: algunos sostuvieron en su oportunidad que su orientación sexual podría generar cierta inhabilidad para investigar los delitos y hechos circundantes al caso Spiniak. Pero, aparte de eso, sí se pudo justificar (legalmente) la intromisión en su vida privada y sacarlo del caso Spiniak merced a las normas legales que dicen relación con el decoro con que se deben comportar los jueces": Figueroa (2014), p. 92

${ }^{87}$ ADN Radio, Terra, Radio Cooperativa, El Mercurio, La Cuarta, La Tercera, El Mostrador, El Sur, La Nación, La Estrella, Publimetro, La Hora, LUN y Ciper. 
abogado de la banda de narcotraficantes de la población la Victoria... Vinculan a oficial policial con 'Los Carejarro's8.

A su turno, el Diario El Mercurio ("El Mercurio") publicó el suceso en la edición del 1 de julio de 2008, titulándolo (en página A-1) "Carabineros expulsa a un comandante y la Fiscalía Sur suspende a funcionario por nexos con narcos". La nota, en página C-989, decía lo siguiente: "Carabineros expulsó ayer al Comandante Juan Loyola Villalobos, de la Dirección de Fronteras y Servicios Especiales, por sus vinculaciones con la banda de los 'Carejarro' de La Victoria...". Luego, aludiendo a la fuente, señala que Loyola "intercedió ante personal subalterno para evitar que se cursara una infracción al tránsito. [Fue] sólo esa relación con el abogado. No hay hasta el momento ningún antecedente que lo relacione con la organización".

Pues bien, Loyola demandó a los periódicos la indemnización de los daños materiales y morales derivados de dichas publicaciones, obteniendo sendas sentencias favorables.

Los jueces del fondo esgrimieron argumentos parecidos.

Sin embargo, la Corte Suprema deliberó sobre la sustancia del asunto sólo en el caso contra El Mercurio, lo que amerita un análisis más detenido. En cambio, declaró inadmisible el recurso de casación en el fondo interpuesto por La Cuarta en contra del fallo de alzada.

\subsubsection{Juicio contra La Cuarta}

La sentencia de primer grado pronunciada contra La Cuarta desestimó la acción principal por haberse fundado en el delito de injuria -que habrían cometido directivos del periódico-, cuya existencia no fue establecida en sede penal, pero acogió la acción subsidiaria que fue basada en los arts. 2314 y siguientes.

Dicho fallo consideró que las noticias publicadas por La Cuarta eran injuriosas -el titular hablaba por sí solo- y falsas, pues no se acreditó vinculación alguna entre Loyola y los narcos.

Por el contrario, estimó como probado el hecho de que Loyola no fue expulsado sino que presentó su renuncia voluntaria a Carabineros el mismo día

\footnotetext{
${ }^{88}$ La nota añade: "Se fue al lado oscuro... El comandante de Carabineros Juan Loyola fue expulsado de la institución debido a los vínculos que tendría con el abogado Ariel Marín, defensor de los narcos que integran la peligrosa banda de 'Los Carejarro'. A él se podría sumar un coronel en retiro de la policía uniformada... Una inmediata expulsión de la institución decretó ayer Carabineros para el ahora ex comandante Juan Loyola Villalobos, debido al vínculo que posee con el abogado Ariel Marín, defensor de los integrantes de la banda de narcotraficantes conocida como 'Los Carejarro"'.

${ }^{89}$ Bajo el epígrafe "Investigación a banda de los Carejarro de la Población la Victoria: Oficial de Carabineros y empleado de Fiscalía Sur caen por nexos con narcos".
} 
30 de junio de 2008, fecha en que la institución ordenó instruir un sumario administrativo en su contra.

En síntesis, para el sentenciador de primera instancia, "la demandada incurrió en una infracción a un deber de cuidado en la entrega de la información, por cuanto efectuó una afirmación que no se ajustaba a la realidad, no siendo efectivo, como sostiene al contestar la demanda, que se hablara en términos condicionales, dado que la noticia da cuenta que el actor habría sido expulsado por Carabineros de Chile por su vinculación con la banda delictual 'Los Carejarro'. Que efectivamente, como lo sostiene la demandada, nuestra constitución consagra el legítimo ejercicio de la libertad de informar y emitir opinión, pero eso no puede ser motivo para que en la portada del diario se afirme que el actor fue expulsado de carabineros por vínculos con 'los Carejarro', lo que como se concluyó precedentemente nunca ocurrió" ${ }^{\prime 90}$.

Con todo, este argumento se contrapone a la doctrina que dicha sentencia cita unos cuantos párrafos antes, precisamente para apreciar la conducta de la demandada, a saber:

"Que, para efectos de analizar lo referido en el libelo respecto a las expresiones falsas e injuriosas que habría efectuado la demandada en la publicación de 1 de julio de 2008 en el Diario La Cuarta, edición 8.005, cabe señalar que '...es una tendencia uniforme del derecho privado contemporáneo que la responsabilidad por expresiones exija, como condición para atribuir responsabilidad civil, que en la difusión de información errónea se haya incurrido en infracción de un deber de cuidado... Así, la responsabilidad comienza sólo donde cesa toda excusa mínimamente aceptable, de modo que se establece un predominio abstracto de la libertad de información sobre la honra' (Tratado de Responsabilidad Extracontractual, Enrique Barros Bourie, Editorial Jurídica, página 581 $)^{91}$.

Luego, la sentencia aludida adhiere a la idea de que la responsabilidad civil de los Medios se sustenta en la infracción de un deber de cuidado -el de divulgar información veraz o verosímil, mas no cierta o efectiva- pero colige que La Cuarta transgredió tal deber "por cuanto efectuó una afirmación que no se ajustaba a la realidad"92.

Así, el juez dio lugar a la indemnización del daño moral pero desestimó el daño emergente y el lucro cesante por ausencia del nexo causal: estos perjuicios

$905^{\circ}$ Juzgado Civil de Santiago, rol No 14560-2012, 28 de octubre de 2014, cons. $18^{\circ}$.

$915^{\circ}$ Juzgado Civil de Santiago, rol No 14560-2012, 28 de octubre de 2014, cons. $15^{\circ}$.

$925^{\circ}$ Juzgado Civil de Santiago, rol No 14560-2012, 28 de octubre de 2014, cons. $18^{\circ}$. 
no provinieron de la publicación sino del retiro de Loyola, ello a raíz del sumario administrativo iniciado el día anterior a la publicación.

Por su parte, la Corte de Apelaciones de Santiago, confirmando el fallo en alzada, declaró lo siguiente: "Una publicación como la hecha en el diario de la demandada, en primera página, señalando que el demandante, un alto oficial de Carabineros, 'se fue de PLR por vínculos con Los Carejarro', no sólo menoscaba por lo falsa sino por lo altamente ofensiva de sus términos, sin que sea excusa que ese es el estilo del diario. Tiene derecho la demandada a publicar y a hacerlo en términos populares o jocosos, mas debe responder -no sólo en virtud de la Ley $N^{\circ} 19.733$ sino también de acuerdo a lo dispuesto en los artículos 2314 y siguientes del Código Civil- si con ello comete un delito o cuasidelito civil" ${ }^{\prime 93}$.

Sin embargo, si, como resulta de los antecedentes del proceso de que da cuenta la sentencia de primera instancia, el periódico se conformó en su actuar al estándar de veracidad y cuidado exigibles, consultó las fuentes pertinentes y se cercioró de la verosimilitud de la información previo a su divulgación, dentro del escaso tiempo con que contaba, el hecho de que en el juicio resarcitorio posterior se haya probado que la información no era veraz demuestra que el semanario demandado incurrió en un error y que éste excluye su negligencia.

El problema, a mi entender, es que la Corte parece haber confundido la verdad con la veracidad. Esto envuelve un serio riesgo de vulneración de la libertad de informar sobre hechos de interés general que afectan a personas públicas y que inciden en su desempeño.

Peor aún. El riesgo referido se actualizará cada vez que la jurisprudencia haga responder a la prensa de los daños derivados de la difusión de noticias sobre hechos de interés social que, a la fecha de su divulgación, eran razonablemente verosímiles ${ }^{94}$.

\subsubsection{Juicio contra El Mercurio}

Loyola también demandó a El Mercurio la reparación del daño emergente, el lucro cesante y el daño moral que le habría causado la divulgación sensacionalista de información falsa, mancillando su honra e imagen.

\footnotetext{
${ }_{93}$ Corte de Apelaciones de Santiago, rol No 438-2015, 15 de abril de 2015, cons. $6^{\circ}$. La Corte Suprema (rol Nº 6736-2015, 13 de julio de 2015) rechazó los recursos de casación interpuestos en contra del fallo de alzada.

94 "Lo cierto es que el deber de diligencia se acredita con la prueba de una investigación periodística seria y no requiere demostrar la verdad de la información, pues de ser así el medio de comunicación demandado jamás podría alegar una excusa ante las noticias inexactas y respondería invariablemente cada vez que exista un error en la información divulgada": DANIEL (2016), p. 91.
} 
Loyola alegó que renunció a Carabineros el 30 de junio de 2008 y negó toda vinculación con el mentado grupo narcotraficante.

Fundó su acción principal en el delito de injuria, tipificado en el art. 40 de la Ley No 19.733 de 2001, demandando subsidiariamente la indemnización de perjuicios ex arts. 2314 y 2329.

Por su parte, El Mercurio solicitó el rechazo del libelo en atención a los siguientes argumentos:

i) No existe nexo causal entre la noticia y los daños, pues, aun si éstos fuesen efectivos, emanaron de la renuncia de Loyola, reacción explicable ante el sumario que Carabineros ordenó instruir en su contra;

ii) El reportaje no falseó los hechos sino que informó, como los demás Medios, de la declaración efectuada por la institución la noche anterior, en el sentido que Loyola sería expulsado por sus lazos con un miembro de la banda criminal;

iii) Ninguna responsabilidad civil se sigue de un delito penal no establecido por sentencia firme;

iv) Loyola es el único causante de los daños pues él renunció a Carabineros antes de la publicación, exponiéndose imprudentemente al daño al mantener contactos con un integrante de la asociación criminal;

v) El daño moral resultante de imputaciones injuriosas sólo es resarcible si el TC declara inaplicable el art. 2331, cuyo no es el caso.

En el proceso se acreditó que El Mercurio tomó conocimiento de la renuncia de Loyola con posterioridad a la publicación, cuando preparaba su defensa, descubriendo este antecedente al revisar el expediente de la causa dirigida contra La Cuarta.

En efecto, El Mercurio acompañó copia de la renuncia con el objeto de probar que los daños - de ser ciertos- no emanaron de la noticia sino de la propia decisión del actor.

El Mercurio demostró que Carabineros abrió un sumario administrativo en contra de Loyola el 30 de junio de 2008 por los hechos comunicados en conferencia de prensa esa noche; que Loyola fue reincorporado a la institución el 11 de julio de 2009, después que la Corte Marcial anulara su procesamiento por supuestos delitos de fraude al Fisco y malversación de caudales públicos; que Loyola descendió al último grado de los oficiales de su generación al haber transcurrido más de 6 meses desde su renuncia, concediéndosele el retiro definitivo el 1 de marzo de 2011; y que, previo a la publicación, El Mercurio confirmó con dos fuentes autónomas -en la Fiscalía Sur y Carabineros- que Loyola habría intercedido a favor de Ariel Marín, formalizado por narcotráfico, para evitar que fuera multado por una infracción del tránsito. 
Los jueces del fondo rechazaron la acción principal por no existir el delito penal en que se fundó. También desestimaron la acción subsidiaria respecto de los daños patrimoniales, toda vez que éstos derivaron de la renuncia del actor y no de la noticia.

Sin embargo, sobre la base de la renuncia de Loyola el juez a quo presumió la culpa de El Mercurio, negligencia que hizo consistir en el hecho de haber informado un hecho falso que irrogó daño moral al actor ${ }^{95}$.

El tribunal de alzada capitalino confirmó el fallo apelado. Al efecto, enfatizó que El Mercurio asoció la expulsión de Loyola a sus supuestos lazos con los narcotraficantes pese a que la fuente citada en el reportaje afirmó que no había ningún antecedente que los relacionara. Así, la sentencia de segundo grado concluyó que El Mercurio "obró con culpa evidente al destacar la existencia de tales nexos tanto en la portada como en los titulares del cuerpo interior. Es decir, cuando efectuó la publicación de la manera antes indicada, y sabiendo que tales vínculos no se habían establecido, actuando desaprensivamente, informó como si fueren efectivos, relacionando a ellos la salida de Carabineros del actor. Por tanto, la demandada sabía que la información no tenía caracteres de veracidad"96.

El Mercurio dedujo recursos de casación en la forma y en el fondo. En lo que aquí interesa, el demandado fundó este último recurso en la infracción de los arts. 44, 1459, 1698 y 2331.

El Mercurio reprochó al fallo recurrido haber alterado la carga de la prueba pues i) dio por acreditada la culpa únicamente con las copias de la noticia y de la carta de renuncia, desconociendo que este documento fue acompañado para otro fin -negar el nexo causal entre la publicación y los daños-; y ii) presumió la mala fe de la demandada (esto es, que sabía que el actor no tenía vínculos con los narcos) pese a la falta de pruebas.

El Mercurio alegó que el fallo recurrido leyó de modo sesgado el reportaje, ya que no analizó la frase "(Fue) sólo esa relación con el abogado" que precede a la oración "no hay hasta el momento ningún antecedente que lo relacione con la organización". Según el recurrente, el fragmento preterido demuestra que las fuentes que consultó admitieron que Loyola tenía un vínculo con Ariel Marín, razón por la cual Carabineros abrió un sumario en contra de aquél.

La Corte Suprema desestimó ambos recursos, en particular el de casación en el fondo, en atención a los siguientes argumentos:

$9525^{\circ}$ Juzgado Civil de Santiago, rol № 13478-2012, 26 de octubre de 2015.

${ }^{96}$ Corte de Apelaciones de Santiago, rol № 433-2016, 13 de julio de 2016, cons. $8^{\circ}$. 
i) No se alteró la carga de la prueba sino que la demandada discrepó del raciocinio efectuado en el fallo recurrido ${ }^{97}$;

ii) "El propio texto de la noticia publicada por la recurrente resulta suficiente para determinar la negligencia en que dicha parte incurrió al anunciar en sus titulares una circunstancia que la información proporcionada por la fuente no autorizaba a concluir"98;

iii) La imprudencia es suficiente para atribuir responsabilidad sin requerirse dolo o culpa lata ${ }^{99}$;

iv) La libertad de informar reconoce como límites los delitos penales y abu$\operatorname{sos}^{100}$, esto es, hechos dolosos o culpables que causan daño, el que debe ser reparado ex arts. 2314 y $2329^{101}$;

v) El art. 2331 debe ser interpretado en congruencia con el reconocimiento del daño moral, que es el tipo de perjuicio que naturalmente ocasionan las imputaciones injuriosas, sin cuya reparación se afectaría en su esencia el derecho a la honra ${ }^{102}$;

vi) El daño moral sólo podría quedar excluido tratándose de imputaciones injuriosas pero no ante una violación al derecho a la intimidad e imagen en el que también se basó el libelo ${ }^{103}$;

vii) No existiendo vínculos entre Loyola y los narcos no cabe rebajar la indemnización según el art. 2330 ${ }^{104}$.

\section{Aproximación crítica}

Estas sentencias son una mala noticia para la libertad de información. Un periódico no debería asumir responsabilidad patrimonial alguna si, habiendo confrontado las fuentes, transmite lo aseverado por éstas y difunde circunstancias fácticas que concitan el interés general y conciernen a quienes deben rendir cuenta de su comportamiento ante el público.

${ }_{97}$ Corte Suprema, rol No 65403-2016, 13 de junio de 2017, cons. $9^{\circ}$.

${ }^{98}$ Corte Suprema, rol No 65403-2016, 13 de junio de 2017, cons. $10^{\circ}$.

${ }^{99}$ Corte Suprema, rol No 65403-2016, 13 de junio de 2017, cons. $10^{\circ}$.

100 Art. 19 N 12 CPR, art. 13.2 Pacto de San José de Costa Rica, y art. 1º, Ley № 19.733, de 2001.

${ }^{101}$ Corte Suprema, rol No 65403-2016, 13 de junio de 2017, cons. 11-12.

${ }^{102}$ Corte Suprema, rol № $65403-2016,13$ de junio de 2017, cons. $13^{\circ}-15^{\circ}$.

${ }^{103}$ Corte Suprema, rol No 65403-2016, 13 de junio de 2017, cons. $16^{\circ}$ (citando Corral (2006), p. 276) y $17^{\circ}$.

${ }^{104}$ Corte Suprema, rol No 65403-2016, 13 de junio de 2017, cons. $19^{\circ}$. 
El juicio de responsabilidad civil supone de una correcta ponderación de valores en permanente fricción, como lo ilustra la tensión entre el derecho a la honra de una persona y la libertad de expresión de los Medios.

Lo anterior exige distinguir los casos que atingen a personas comunes y corrientes, cuya honra merece una protección jurídica más intensa que la de una persona pública, de las situaciones que atañen a personas que ostentan un cargo público, de cuyo desempeño responden ante la sociedad.

Así, la atribución de responsabilidad por mera negligencia es una manera adecuada de preservar la honra de las personas comunes y corrientes. En efecto, esta regla permite dirimir la colisión entre el derecho a la libertad de informar que tienen los Medios y el derecho a la honra de esta clase de personas, reconociendo que éste ha de prevalecer y que la vulneración culpable del mismo habilita a la víctima para impetrar su indemnización por aplicación del principio de reparación integral consagrado en los arts. 2314 y siguientes.

En cambio, tratándose del segundo grupo de casos, se hace necesario reinterpretar el estatuto general de responsabilidad civil de suerte que los Medios se hagan cargo de los daños que infligen a la honra de personas públicas únicamente si abusan de modo particularmente grave de su derecho a la libertad de expresión.

Este abuso, como se ha argumentado respecto de la responsabilidad civil por actos de competencia desleal y conductas anticompetitivas, es un comportamiento caracterizado por el dolo o el total desprecio de su autor hacia el adversario $^{105}$, actitud esta última constitutiva de dolo eventual o, quizá mejor, de la culpa lata que el CC equipara al primero ${ }^{106}$.

En efecto, así como la libertad de competir de un agente económico perjudica -inexorable y previsiblemente- los intereses económicos de los rivales vencidos por aquél, el ejercicio de la libertad de expresión asimismo afecta, inevitable y previsiblemente, la honra ajena.

Este hecho determina la necesidad de calificar las reglas generales de la responsabilidad civil de forma coherente con la naturaleza de las actividades competitivas y periodísticas que, sin dudas, son económica, social y políticamente beneficiosas.

Esto supone restringir la responsabilidad civil entre competidores mediante algún factor que permita una justa ponderación de la libertad de actuación de unos -cuyo ejercicio inexorable y previsiblemente menoscaba a otros- y el derecho a la seguridad de las víctimas.

\footnotetext{
105 Barros (2006), pp. 1047-1049; Banfi (2011), (2013), (2014) y (2017).

106 BANFI (2003) y (2012).
} 
Análogamente, el derecho a la libertad de informar de que son titulares los Medios, debe ser sopesado con el derecho a la honra de las personas públicas que, a diferencia de un ciudadano de a pie, están naturalmente expuestas al juicio de la comunidad a quien interesa sobremanera vigilar su actuación.

El elemento que permite zanjar el dilema e inclinar la balanza a favor del derecho de la persona pública a ser indemnizada cuando su reputación es conculcada a través de la difusión de noticias falsas, no es ni puede ser la mera negligencia.

La responsabilidad civil de los Medios, en este tipo de casos, no puede basarse en el descuido ordinario porque ello limitaría de forma desmesurada el derecho de los Medios a informar acerca de hechos de gravitación social.

En efecto, si el simple cuasidelito generara la responsabilidad civil de los Medios, la actividad periodística correría el serio riesgo de disminuir a un nivel precario e inconsistente con la relevancia que un sistema democrático asigna a la información sobre hechos de interés social en los que han participado personas públicas.

Pero existe otra razón para excluir la mera negligencia como condición de la responsabilidad patrimonial de los Medios en esta clase de situaciones: la culpa no excluye el error en la difusión de hechos o noticias falsas pero que al momento de ser comunicados estaban revestidas de una razonable veracidad.

Por consiguiente, tratándose de pleitos que conciernen a personas públicas, el abuso del derecho a la libertad de expresión de los Medios que es susceptible de neutralizar la causal de justificación que de otro modo operaría, requiere de una calificación adicional, a saber: debe tratarse de un comportamiento extremo consistente en la divulgación de noticias falsas a sabiendas (de mala fe), dolosamente (con intención de dañar como un fin o como un medio para otro fin) o, al menos, con suma desconsideración hacia la posibilidad de lesionar la honra de las personas públicas involucradas en los hechos noticiosos respectivos (dolo eventual o culpa grave).

Por eso, no deja de sorprender que la Corte Suprema, pese a confirmar el fallo de primera instancia dictado contra El Mercurio -el que aseveró que "la responsabilidad comienza sólo donde cesa toda excusa mínimamente aceptable, de modo que se establece un predominio abstracto de la libertad de información sobre la honra"107-, concluya que el mero descuido de la prensa es suficiente para hacerla responder de los daños causados a una persona pública, en circunstancias que para el profesor Enrique Barros Bourie, autor del aserto

$10725^{\circ}$ Juzgado Civil de Santiago, rol No 13478-2012, 26 de octubre de 2015, cons. $18^{\circ}$, citando a BARROS (2006), p. 581. 
Por unA RESPONSABILIDAD CIVIL DE LOS MEDIOS DE COMUNICACIÓN COHERENTE CON EL RIESGO DE DIVULGACIÓN DE NOTICIAS FALSAS SOBRE PERSONAS PÚBLICAS

que hicieron suyo los jueces del fondo, en casos de esta índole "el umbral de responsabilidad parece no ser lejano a la culpa grave"108.

Igualmente inadecuado me parece que los jueces de las instancias y la Corte Suprema imputen mala fe -el hecho de publicar una noticia a sabiendas de su falta de veracidad- a partir de un examen o lectura parcial de la nota periodística en cuestión.

En efecto, el deber de cuidado exigible a los Medios no consiste en corroborar la verdad sino la veracidad de lo que pretenden informar. Esto significa que, si con posterioridad se prueba que lo publicado no era cierto, se estará ante un error.

Por eso, la prensa no debería incurrir en responsabilidad patrimonial si por equivocación -e incluso con imprudencia que, como indiqué, no elimina el error- divulga información falsa relativa a personas públicas involucradas en hechos de interés social, pero que a la fecha de difundirla era razonablemente creíble.

Esta afirmación obedece al hecho de que la sociedad está más dispuesta a aceptar el riesgo de que los Medios comuniquen erróneamente noticias falsas -yerro que la mera negligencia no borra- a tolerar el riesgo de que hechos que revisten interés general pues repercuten en el cumplimiento de las funciones encomendadas a personas públicas, sean silenciados.

En concreto, si un periódico transmite información dada a conocer públicamente en rueda de prensa, cuya verosimilitud ratificó con las fuentes y en los tiempos disponibles, no debería hacerse cargo de los daños alegados por quien fue objeto de la noticia.

Se trataría sólo de un reportaje neutral, ya que "el objeto de la noticia ha de estar constituido por declaraciones que imputan hechos lesivos del honor pero que han de ser noticia por sí mismos y han de ponerse en boca de personas determinadas responsables de ellas, y que el medio informativo ha de ser mero transmisor de tales declaraciones, limitándose a narrarlas sin alterar la importancia que tengan en el conjunto de la noticia"109.

En efecto, "la libertad de información, dado su objeto de puesta en conocimiento de hechos, cuando comporta la transmisión de noticias que redundan en descrédito de la persona, para que pueda prevalecer sobre el derecho al honor exige que la información cumpla el requisito de la veracidad, como resultado de una razonable diligencia por parte del informador para contrastar la noticia de acuerdo con pautas profesionales ajustándose a las circunstancias del caso,

\footnotetext{
${ }^{108}$ Barros (2006), pp. 581-582.
}

109 STS 4964/2004, cons. $3^{\circ}$. 
aun cuando la información, con el transcurso del tiempo, pueda más adelante ser desmentida o no resultar confirmada... Faltaría esa diligencia cuando se transmiten como hechos verdaderos simples rumores carentes de constatación o meras invenciones... La transmisión de la noticia o reportaje no puede sobrepasar el fin informativo que se pretende dándole un matiz injurioso, denigrante o desproporcionado, porque, como viene reiterando el Tribunal Constitucional, la Constitución no reconoce un hipotético derecho al insulto"110.

En suma, la lectura completa de la noticia publicada por El Mercurio habría permitido a los jueces del fondo y a la Corte Suprema descartar no sólo la culpa sino también la mala fe del demandado.

Ello habría evitado la construcción de una presunción de dolo, altamente peligrosa para la libertad de informar, basada en que la información divulgada -según las pruebas rendidas en el juicio de responsabilidad posterior- resultó no ser efectiva.

Sucede, sin embargo, que El Mercurio mal pudo mentir si se limitó a reproducir lo aseverado por la fuente consultada: que Loyola tuvo un nexo con un integrante de una asociación ilícita.

El hecho de que la afirmación publicada sea desmentida en el pleito indemnizatorio ulterior no permite colegir culpa o dolo sino un error del demandado. Este yerro, incluso unido al descuido, no justifica la imputación de responsabilidad civil en el tipo de casos reseñado.

\section{Límites de la responsabilidad civil de los Medios: mala fe, dolo eventual y culpa lata}

\section{En la jurisprudencia chilena}

Dado lo anterior, mientras no exista una reforma legal como la que hace años dormita en el Congreso ${ }^{111}$, los Medios deberían responder de los daños ocasionados a las personas públicas a consecuencia del ejercicio particularmente abusivo de su libertad de informar, esto es, si divulgan noticias falsas a sabiendas, con total indiferencia respecto de su veracidad o con culpa grave.

Este criterio no es desconocido por la Corte Suprema. En efecto, de alguna manera, el dolo civil -o culpa lata equivalente al primero-en que debe incurrir

\footnotetext{
110 STS 4544/2016, cons. $3^{\circ}$.

${ }^{111} \mathrm{El}$ art. $2^{\circ}$ del Proyecto sustituye al art. 40 de la Ley $\mathrm{N}^{\circ} 19.733$ de 2001 por uno que incorpora al art. 2331 un inciso $3^{\circ}$, a saber: "En caso de que se ejerza la acción civil por imputaciones contrarias a la honra o atentados a la vida privada o imagen de la persona independiente a la responsabilidad penal, la indemnización de los daños sólo procederá si se han cometido con dolo o culpa grave y no concurra alguna circunstancia que justifique la difusión como aquellas previstas en el artículo 30 de esta ley".
} 
el medio de comunicación para que surja su responsabilidad, es análogo al dolo del delito de injuria que, como señala la Corte Suprema, consiste en "saber que la expresión que se proferirá o la acción que se ejecutará es deshonrosa para quien está referida, o desacreditadora o menospreciadora de éste, y en querer proferirla o ejecutarla"112.

Este parámetro también ha sido compartido por ex miembros del TC: "Que como lo reconoce la jurisprudencia internacional, para que proceda la indemnización del daño moral por imputaciones injuriosas debe acreditarse malicia o grave negligencia, es decir, que los dichos fueron pronunciados con el propósito de causar daño o al menos que no se tomaron todas las medidas necesarias para verificar la seriedad de las fuentes que justificaran su verosimilitud, con un claro desprecio por su veracidad o que no existía razón alguna que los pudiera justificar. Este criterio es corroborado por el principio 10 de la Declaración de Principios sobre Libertad de Expresión, 31 de enero de 2003, del Sistema Interamericano: ' ... debe probarse que en la difusión de las noticias el comunicador tuvo intención de infligir daño o pleno conocimiento de que se estaban difundiendo noticias falsas o se condujo con manifiesta negligencia en la búsqueda de la verdad o falsedad de las mismas". Esta doctrina fue expresada por la Corte Suprema de Estados Unidos en el paradigmático caso New York Times versus Sullivan. Por su parte, el Tribunal Constitucional de España ha afirmado que se trata de dilucidar cuándo la libertad de expresión actúa como "excluyente de la antijuridicidad" (caso Navazo, rol No 107/1988)"113.

\section{El paradigma norteamericano}

Pero es el derecho estadounidense el que ha llevado a un sector minoritario de la doctrina civil chilena a concluir que la honra de las personas públicas

\footnotetext{
${ }^{112}$ Corte Suprema, rol No 4642-2006, 4 de julio de 2007, cons. $11^{\circ}$.

113 TC, rol No 1723-2010, 24 de mayo de 2011, voto de Ministros Carmona y Viera-Gallo, cons. 15º (apoyando la propuesta de Ministro Bertelsen por la derogación parcial del art. 2331). El Tribunal Constitucional español sigue el precedente sentado en New York Times v. Sullivan, lo que es criticado por Fernando Pantaleón como un trasplante de una solución propia de los torts, que comprenden los daños punitivos, a la responsabilidad civil: YzQuierdo (2014), p. 1397, № 36. Sin embargo, dicha sentencia incluye ante todo la indemnización compensatoria. Además, la corte revocó el fallo de alzada que había condenado al demandado a pagar US\$ 500.000 sin diferenciar la parte correspondiente a indemnización (respecto de la cual las leyes de Alabama facultan al juez para presumir la malicia de la sola afirmación difamatoria) de la que dice relación con los daños punitivos (en cuyo caso debe probarse la malicia). En lo sucesivo el actor tendrá que probar que el demandado publicó información falsa a sabiendas o despreciando su veracidad para reclamar tanto daños compensatorios como punitivos: New York Times v. Sullivan, pp. 283-284.
} 
debería prevalecer sobre la libertad de expresión de los Medios, siempre que éstos publiquen información falsa a sabiendas o despreciando su veracidad ${ }^{114}$.

Es decir, la responsabilidad civil de los Medios debería quedar supeditada a una regla similar a la instaurada en el célebre caso New York Times v. Sullivan, a saber:

"La garantía constitucional [de la libertad de expresión consagrada en la Primera Enmienda de la Constitución de 1787 ${ }^{115}$ ] exige, pensamos, una regla federal que prohíba a un funcionario público cobrar perjuicios por una falsedad difamatoria referida a su conducta oficial a menos que pruebe que la declaración fue hecha con 'malicia real', esto es, a sabiendas de su falsedad o con imprudencia temeraria de si era falsa o no"116.

En importantes sentencias posteriores la Corte Suprema norteamericana ha profundizado este precedente. En este sentido, declaró que actúa con malicia el periódico que publica una afirmación falsa fundándose sólo en la versión de los hechos proporcionada por terceros de dudosa credibilidad y que además omite investigar con mayor acuciosidad pese a haber tenido tiempo para hacerlo. En cambio, no incurre en malicia el diario que, apremiado por la necesidad de divulgar rápidamente una información, la difunde basándose en el relato de personas competentes y dignas de confianza ${ }^{117}$.

Asimismo, esta Corte ha estimado que, en principio, la falta de una indagación minuciosa de los hechos no implica que el periódico haya actuado con malicia'118.

Salvo que ello obedezca a la decisión consciente del demandado de no averiguar más sobre hechos que, con razonable probabilidad, le habrían permitido confirmar la falsedad de la información que se proponía publicar y que de hecho divulgó. En efecto, en este último caso, quedaría de manifiesto que el demandado evitó deliberadamente conocer la verdad ${ }^{119}$.

En todo caso, en New York Times v. Sullivan se estableció que no es necesario probar que el demandado tuvo intención de dañar al actor como un fin (por odio o mala voluntad) ${ }^{120}$. Sin embargo, como ha declarado la Corte con

114 Anguita (2005), pp. 25 y 408-409; Barros (2006), pp. 85-86, 112-113, 537-539 y 577-582; FedderSeN (2008), pp. 85-86; PINO (2014); Daniel (2016), pp. 113-115.

115 "Congress shall make no law...abridging the freedom of speech, or of the press...".

116 New York Times v. Sullivan, pp. 279-280.

117 Curtis Publishing v. Butts, p. 158.

118 St. Amant v. Thompson, pp. 732-733.

119 Harte-Hanks Communications v. Connaughton, p. 692.

120 New York Times v. Sullivan, p. 284; EpSTEIN y Sharkey (2012), p. 1018. 
posterioridad, dicho dolo puede servir -junto a otros antecedentes- para comprobar que el demandado tuvo serias dudas sobre la veracidad de lo que quería difundir y que, a pesar de ello, lo publicó ${ }^{121}$.

En definitiva, New York Times v. Sullivan continúa plenamente vigente y ha sido recogido en sendos preceptos del Restatement (Second) of Torts, a saber:

i) "Quien publica una comunicación falsa y difamatoria sobre un funcionario público o una figura pública respecto de su conducta, aptitud o función en tal condición está sujeto a responder si, pero sólo si, (a) sabe que la declaración es falsa y que difama a la otra persona, o (b) actúa con indiferencia temeraria respecto de estas materias"122, y

ii) "Quien publica una comunicación falsa y difamatoria concerniente a una persona privada, o sobre un funcionario público o una figura pública en relación a un asunto estrictamente privado que no afecta su conducta, aptitud o función en su condición pública, debe responder si, pero sólo si, (a) sabe que la declaración es falsa y que difama a la otra persona, (b) actúa con indiferencia temeraria respecto de estas materias, o (c) actúa negligentemente al afirmarlas ${ }^{\prime 123}$.

Con posterioridad, la Corte Suprema estadounidense ha declarado que la regla fijada en New York Times v. Sullivan se circunscribe a casos que involucran figuras públicas ${ }^{124}$, insistiendo que ésta no tiene aplicación respecto de personas comunes y corrientes ${ }^{125}$.

Como argumenta Schauer, el precedente forjado por New York Times v. Sullivan obedece en gran medida al contexto socio-político de la época. Bajo otras circunstancias, la Corte Suprema seguramente habría denegado la solicitud de certioari sin verse compelida a restringir la responsabilidad civil a la publicación maliciosa de información falsa ${ }^{126}$.

En todo caso, aun cuando no existan presiones político-sociales de la magnitud del movimiento reivindicatorio de los derechos civiles que conmocionó a los Estados Unidos en la década de 1960, es inconcuso que el valor preeminente que se reconoce a la libertad de expresión en una democracia favorece la limitación de la responsabilidad patrimonial de los Medios, tratándose de

\footnotetext{
${ }^{121}$ Celle v. Filipino Reporter Enterprises, §§ 36-38.

122 Sección 580A, ReSTATEMENT (SECOND) OF TORTS, actualizado al año 2017.

123 Sección 580B, Restatement (SECOND) OF TORTS, actualizado al año 2017.

${ }^{124}$ Curtis Publishing Co. v. Butts.

${ }^{125}$ Gertz v. Robert Welch, Inc.

${ }^{126}$ SChauer (2006), pp. 901-902 (mostrando, además, que dicho fallo no ha sido seguido en Australia, Canadá, India, Nueva Zelandia, Reino Unido y Sudáfrica, entre otros Estados).
} 
la divulgación de noticias que repercuten en el desempeño de las funciones entregadas a personas públicas.

\section{Otras jurisdicciones del common law}

Ahora bien, la regla de la malicia no es la única vía jurídica para resolver los juicios de responsabilidad civil entre los Medios y las personas públicas. En efecto, como aduce Tushnet, el requisito del dolo se justifica en un sistema en que el derecho de los Medios a ejercer su libertad de expresión tiene una trascendencia tal que relega la honra de las personas públicas a un segundo plano y no le reconoce el carácter de derecho sino de un simple interés.

Según Tushnet, la regla de la malicia tendría además la virtud de disminuir el riesgo de que los tribunales inferiores se desvíen de los principios dictados por los tribunales superiores, dada la imposibilidad práctica de que éstos revisen los fallos pronunciados por aquéllos.

Sin embargo, Tushnet admite que en otros países adscritos al common law, donde el riesgo aludido es menor y donde la libertad de informar de los Medios es un derecho situado en un plano de igualdad inicial respecto de la honra de las personas públicas, los tribunales inferiores prefieren someter la responsabilidad civil a estándares diferentes con el objeto de sopesar ambos derechos y finalmente dirimir la colisión optando por la protección de uno de ellos ${ }^{127}$.

En este sentido, Hart señaló que el estándar es una pauta que habilita al juez para valorar críticamente una conducta ${ }^{128}$. Similarmente, Esser sostuvo que el estándar permite al juez decidir si esa actuación se ajusta o no a derecho, esto es, le "proporciona un criterio, por el procedimiento de remitir a las concepciones vivientes de lo que es valor, deber o diligencia, o también por inclusión de un concepto valorativo que ha de ser substanciado a discreción del juez...el estándar... de la información periodística lícita, de la seguridad del tráfico... etc., determinan, cada uno en su materia, el grado aplicable de tolerancia jurídica" ${ }^{129}$.

Si bien tanto los principios como las reglas son estándares, el juez, como aclarara Dworkin no aplica sino que pondera los principios toda vez que éstos le dan razones para resolver el pleito en una u otra dirección. En cambio, como las reglas son binarias, el juez las aplica o no al conflicto sometido a su decisión ${ }^{130}$.

\footnotetext{
127 TUSHNET (2014), pp. 342-344.

${ }^{128}$ HART (1961), p. 32.

${ }^{129}$ ESSER (1961), pp. 124-125.

${ }^{130}$ Los principios tienen una dimensión ausente en las reglas - la dimensión del peso o importancia. Cuando los principios intersectan... quien debe resolver el conflicto tiene que tomar en cuenta el peso relativo de cada uno... Las reglas no tienen esta dimensión... No podemos decir que una regla es más
} 
Pero como observa Tushnet, no es sólo la utilización de estándares, la ponderación de principios y la aplicación de reglas diferentes lo que permite entender por qué la responsabilidad civil de los Medios para con las personas públicas ha transitado un derrotero distinto fuera de los Estados Unidos. En efecto, existen diversos factores institucionales que explican por qué en otras versiones del common law la responsabilidad civil basada en la negligencia no es vista como una cortapisa de la libertad de expresión, a saber:

i) La regla de la malicia no es la única forma de prevenir o atenuar el riesgo de desalentar la divulgación de noticias de interés general que comprometen a funcionarios públicos ante el razonable temor de los Medios de tener que resarcir los daños causados por la difusión de información falsa por error. Por ejemplo, es posible invertir la carga de la prueba y obligar al actor a demostrar la falsedad de la información sin que el demandado tenga que acreditar su veracidad;

ii) La importancia que se concede a la libertad de prensa depende de factores históricos, idiosincráticos y culturales. El ambiente socio-político en que se litigó New York Times v. Sullivan hace dudar de la posibilidad de exportar la regla de la malicia a comunidades jurídicas que no sienten el imperativo de circunscribir la responsabilidad de los Medios;

iii) La regla de la malicia constituye una forma de contrarrestar el riesgo de que el jurado condene a la prensa a pagar ingentes sumas de dinero a título de daños punitivos, contingencia que no se suscita si éstos son prohibidos o el juez tiene facultades moderadoras;

iv) La regla de la malicia es lógica en el proceso civil norteamericano, el cual garantiza a los demandantes un amplio acceso a las pruebas en poder de los demandados. Pero resultaría excesivo requerir al actor que pruebe la malicia del demandado si los antecedentes en posesión de éste son confidenciales ${ }^{131}$.

\section{Una posición crítica de New York Times v. Sullivan}

importante que la otra dentro del sistema de reglas, de modo que cuando dos reglas colisionan una se impone a la otra en virtud de su mayor peso. Si dos reglas chocan, una de ellas no puede ser una regla válida": DWORKIN (1978), pp. 26-27. "...mientras las reglas jurídicas contienen mandatos normativos definitivos, los principios, en cambio, se conciben como 'mandatos de optimización', todo lo cual implica que, en presencia de una contradicción o colisión, los últimos deberán entrar en un juego de balanceo a fin de determinar cuál de ellos ha de prevalecer concretamente, cuestión que no ocurre en el caso de antinomia de reglas jurídicas. Aquí, según mostramos, una de ellas necesariamente debe ser desplazada del sistema, o sea, debe ser invalidada": CONTESSE (2002), p. 91. Ahora bien, el juez sin dudas deduce o construye reglas a partir de los principios. De hecho, la jurisprudencia elabora criterios para resolver casos similares de modo semejante en su intento por mitigar el riesgo de arbitrariedad: BARROS (1984), p. 279.

131 TUSHNET (2014), pp. 344-355. 
No puede ignorarse la acérrima oposición de Epstein al precedente sentado en New York Times v. Sullivan. Este preclaro jurista de la Universidad de Chicago mira con escepticismo la tesis de que ciertas actividades económicas serían tan especiales que estarían sustraídas a las reglas generales aplicables al común de las relaciones humanas. Luego, en su opinión los Medios deberían resarcir los daños infligidos a la honra de las personas públicas bajo la regla clásica del common law, esto es, la responsabilidad estricta por publicar afirmaciones falsas.

En efecto, Epstein estima que la reputación es una forma de propiedad y su mera invasión, como sucede con el tort of trespass, justifica la imputación de responsabilidad patrimonial a su autor. Una responsabilidad estricta con daños compensatorios y punitivos acotados es, según Epstein, una manera perfeccionada de sopesar la libertad de expresión y la honra, pues ella aumenta la certeza de que el difamador se hará cargo de los daños que infiere a terceros.

Por el contrario, a su juicio la regla de la malicia disminuye la probabilidad de éxito del actor al punto que si éste excepcionalmente logra vencer, el juez o el jurado condenará al demandado a pagar sumas exorbitantes a título de daños indemnizatorios y punitivos.

Además, la regla de la malicia generaría una enorme incertidumbre en el resultado del pleito dada la dificultad mayor que representa la prueba de la mala fe o incluso de la indiferencia temeraria, sin que baste demostrar la culpa lata del demandado. Esta complejidad redundaría en la elevación de los costos de litigar, lo que para Epstein constituye un daño o pérdida social irrecuperable.

Luego, New York Times v. Sullivan no genera incentivo económico alguno para que los Medios se preocupen de divulgar información veraz toda vez que la sujeción de su eventual responsabilidad patrimonial a la prueba del dolo o de la desconsideración temeraria reduce a un nivel ínfimo la probabilidad de que sean condenados a resarcir los perjuicios que ocasionan a la honra de las víctimas.

Lo anterior aumentaría la desconfianza del público hacia los Medios ante la imposibilidad de discriminar entre quienes dicen la verdad y quienes mienten. Esto, sin dudas, haría que el prestigio de la prensa se resintiera negativamente.

Por eso, Epstein concluye que la regla de la malicia establecida en New York Times v. Sullivan no contribuye a establecer la verdad ni a rehabilitar la reputación de las personas, que, según este connotado académico, es el único valor social en juego ${ }^{132}$.

132 EpSTEIn (1986), pp. 782-818. 


\section{El derecho anglosajón}

En el Reino Unido los Medios deben resarcir los perjuicios que irrogan a quienes difaman directamente a través de las afirmaciones que publican, presumiéndose la falsedad de éstas.

No se exige que el actor acredite que la imputación fue publicada maliciosamente ya que la difamación da lugar a una responsabilidad estricta.

Sin embargo, si el demandado opone una defensa o privilegio calificado ${ }^{133}$, como es el hecho de publicar una aseveración en un tema de interés general, el demandante tendrá que probar que el primero difundió la aseveración falsa maliciosamente ${ }^{134}$.

En este supuesto, la malicia se tendrá por acreditada si el demandado publicó la información a sabiendas de su falsedad, con indiferencia hacia su veracidad o por un motivo ilegítimo, sea la intención de dañar al actor como un fin -por mala voluntad u odio-, sea la intención de perjudicarlo como un medio para otro fin, generalmente para obtener una ganancia desvinculada de la publicación de información veraz de interés público.

El célebre juez Diplock precisó el contenido y la extensión de la malicia en estos términos: "En general, el derecho inglés reconoce el noveno mandamiento que prohíbe dar testimonio falso contra el prójimo ${ }^{135}$... Pero el interés público de que la ley brinde un medio efectivo para que las personas reivindiquen su reputación contra las calumnias debe acomodarse al interés público adverso de permitir que se comuniquen franca y libremente entre sí en asuntos en los que tienen un deber que cumplir o un interés que proteger. Lo que se publica de buena fe en estos casos tiene un motivo privilegiado y no es susceptible de reclamo aunque sea difamatorio y falso... el privilegio no es absoluto sino calificado...El demandado tiene derecho a la protección que ofrece el privilegio salvo que se acredite algún otro motivo dominante e impropio. La 'malicia expresa' es el término de arte que describe ese motivo. En general, significa malicia en el sentido popular de deseo de dañar a la persona difamada, motivo que el actor comúnmente deberá probar. Pero para contrarrestar el privilegio la intención de dañar debe ser el motivo dominante... el conocimiento de que se producirá dicho efecto no es suficiente si, pese a ello, el demandado actuó

\footnotetext{
${ }^{133}$ En la taxonomía de Hohfeld, el privilegio -que en sentido laxo equivale a la libertad- se opone al deber jurídico -es su negación-y su correlativo es el no-derecho. Las comunicaciones privilegiadas en difamación (las que excluyen la responsabilidad del autor pues actúa en cumplimiento de un deber, salvo que incurra en dolo) son uno de los ejemplos más conspicuos de privilegio: HoHFELD (1913), pp. 32-33 y 39-40.

${ }^{134}$ Speker y McMahon (2014), p. 1590.

135 Éxodo 20, 16.
} 
según un sentido del deber o protegió de buena fe sus propios intereses legítimos. El motivo por el cual una persona publicó una declaración difamatoria sólo puede deducirse de lo que hizo o supo. Generalmente la malicia expresa se tendrá por probada de forma definitiva acreditándose que el demandado no creyó en la verdad de lo que publicó, pues ningún sentido del deber o deseo de proteger sus propios intereses legítimos puede justificar que alguien profiera falsedades sobre otro... Si publica temerariamente una declaración difamatoria falsa, sin considerar o importarle si era cierta o no, será tratado, al igual que en otras ramas del derecho, como si hubiese sabido que tal afirmación era falsa. Pero la indiferencia a la verdad de lo publicado no debe equipararse al descuido, impulsividad o irracionalidad que lo llevó a convencerse de la veracidad de la declaración... En la vida ordinaria es extraño en verdad que las personas formen su convencimiento por un proceso de deducción lógica basado en los hechos determinados mediante una investigación rigurosa de toda la evidencia disponible y de una evaluación juiciosa de su mérito probatorio. Dependiendo de sus temperamentos, preparación, inteligencia, las personas se mueven por prejuicios, confían en su intuición más que en su razonamiento, desprenden rápidamente conclusiones fundadas en evidencia inadecuada y no reconocen el peso del material que puede cuestionar la validez de las inferencias que hacen. Pero a pesar de la imperfección del proceso mental por el cual se forma una creencia ésta puede ser 'honesta', esto es, la creencia positiva de que las conclusiones alcanzadas son auténticas. El derecho no exige más. Incluso una creencia positiva sobre la verdad de lo publicado bajo un privilegio -la que se presumirá auténtica salvo que se pruebe lo contrario- puede no ser suficiente para desechar la malicia expresa si se prueba que el demandado utilizó el privilegio para un propósito distinto de aquel que la ley tuvo en cuenta para otorgarlo. El caso más típico es aquel en que el motivo dominante del demandado no es el deseo de cumplir el deber o de proteger el interés respectivo sino expresar su animosidad o mala voluntad hacia quien difama. Si esto es acreditado la creencia positiva en la verdad de lo publicado no permitirá al difamador invocar la protección del privilegio de que podría disponer en otro caso. Existen otros ejemplos de motivos impropios que anulan el privilegio. El motivo predominante del demandado puede haber consistido en conseguir alguna ventaja para sí desvinculada del deber o interés que es la causa del privilegio. En tal caso, él perderá el beneficio del privilegio a pesar de haber estado convencido de que lo que dijo o escribió era verdadero. Sin embargo, tanto jueces como jurados no deberían apresurarse en concluir que un demandado actuó por motivos inapropiados que le privarían de la protección del privilegio, a menos que estén seguros que él no creyó que lo que dijo o escribió fuese cierto o que fue indiferente hacia su verdad o falsedad... Sólo si su deseo de cumplir con el deber o de proteger el 
interés respectivo no juega un rol decisivo en sus motivos para publicar lo que cree verdadero podrá descubrirse la 'malicia expresa'"136.

De este modo, para poder resolver la tensión entre el derecho a la honra y la libertad de expresión, el juez debe determinar si el demandado se adecuó al estándar de un periodista responsable ${ }^{137}$.

Para ello, el magistrado puede recurrir, de una forma práctica y flexible ${ }^{138}$, a uno o más de los criterios conocidos como "privilegio Reynolds", cuales son: i) la seriedad de la imputación; ii) la naturaleza de la información y el grado en que ésta concierne a un asunto de interés público; iii) las fuentes consultadas (cuyo conocimiento de los hechos puede variar); iv) las gestiones realizadas por el demandado para confirmar que la información era veraz; el estado en que ésta se halla (por ejemplo, si existe una investigación en curso); v) la urgencia en publicar sobre el tema pues las noticias suelen ser perecibles; vi) el haber contactado al actor dependiendo del caso; vii) el hecho de que el artículo incluya la opinión del actor; viii) el tono de la publicación; ix) las circunstancias de tiempo u otras que rodearon a la publicación ${ }^{139}$.

Hasta el año 2013, los Medios podían eximirse acreditando que la imputación publicada refería a un asunto de interés público y que actuaron responsablemente, considerando tanto la oportunidad como la forma en que lo hicieron. Así, en uno de los casos más relevantes se resolvió que el periodista demandado cuyo reportaje indica que un sargento de la policía es objeto de un sumario por cohecho, cumple con el estándar de diligencia si existían indicios que razonablemente le convencieron de que ese oficial participó en los hechos. No es menester que el demandado conociera de las sospechas. Es suficiente que éstas provengan de fuentes confiables o puedan desprenderse de la investigación policial contra el actor ${ }^{140}$. Sin embargo, como se falló en otro litigio de relevancia, para decidir si el demandado actuó razonable y responsablemente

\footnotetext{
${ }^{136}$ Horrocks v. Lowe (1974), pp. 148-151, Lord Diplock.

137 "El fin de las normas sobre difamación es mantener un balance entre la libertad de expresión y el derecho a la reputación": Panday v. Gordon, § 12, Lord Nicholls; SPEker y MCMAhon (2014), p. 1532.

138 "[E]l privilegio Reynolds provee de un grado de protección apropiado a un periodismo responsable que informa sobre asuntos de interés público. El periodismo responsable es el punto en que se establece un balance equilibrado entre la libertad de expresión en materias de interés público y la reputación de los individuos...Si ellos [los periodistas] pretenden beneficiarse con el privilegio han de ejercer la destreza y el cuidado profesionales debidos...Para que este estándar de conducta tenga sentido debe ser aplicado de una forma práctica y flexible": Bonnick v. Morris, §§ 23-24, Lord Nicholls. Véase, también, Jameel v. Wall Street Journal Europe SPRL, §56, Lord Hoffmann.

${ }^{139}$ Reynolds v. Times Newspapers Ltd., p. 205, Lord Nicholls.

${ }^{140}$ Flood v. Times Newspapers Ltd.
} 
sólo puede considerarse la información disponible a la fecha en que aquél escribió el artículo respectivo ${ }^{141}$.

Pues bien, la Defamation Act de 2013 fortaleció la libertad de expresión al sustituir la citada excepción por la defensa del interés público. En virtud de esta última los Medios no responden de los daños causados con la publicación de una afirmación en asuntos de interés público si han creído razonablemente que se trata de esta clase de temas, aunque sepan que la declaración es falsa. Esta ley libera a los Medios de la necesidad de probar que actuaron responsablemente.

Luego, como resume Tushnet, "el Reino Unido parece haber transitado de un derecho jurisprudencial que rechazaba New York Times v. Sullivan por considerarlo demasiado generoso con los Medios hacia un derecho legislado que desecha New York Times v. Sullivan por estimar que no es suficientemente generoso con los Medios"142.

En este sentido, entre nosotros se sugiere que los jueces chilenos podrían tener en cuenta criterios como los referidos a fin de balancear la honra y la libertad de informar en los pleitos indemnizatorios de que conozcan ${ }^{143}$.

\section{Propuesta}

Tratándose de noticias concernientes a funcionarios públicos la colisión entre su reputación y la libertad de expresión debiera resolverse a favor de esta última, salvo que el titular abuse gravemente de ésta.

La trascendencia que reviste la difusión de noticias sobre hechos de interés general que atañen a personas públicas y la necesidad de someterlos al escrutinio de la ciudadanía, exigen proveer al juez civil de pautas para dirimir con prudencia y ecuanimidad dicha tensión ${ }^{144}$.

En efecto, "quien decide buscar un cargo público debe aceptar ciertas consecuencias necesarias de su participación en asuntos públicos. Él corre el riesgo de un escrutinio público más cercano que el que en otro caso tendría... los Medios de comunicación están facultados para actuar asumiendo que los funcionarios públicos y las figuras públicas se han expuesto voluntariamente

\footnotetext{
141 Loutchansky v. Times Newspapers Ltd., § 78, L.J. Brooke; SPeKer y McMahon (2014), p. 1620.

142 TUSHNET (2014), pp. 355-356.

143 PINO (2014).

${ }^{144}$ La derogación del inc. $2^{\circ}$ del art. 19 № 4 CPR -que delegaba en el legislador la tipificación y sanción del ambiguo delito de difamación ("la imputación de un hecho o acto falso, o que cause injustificadamente daño o descrédito a una persona o a su familia")-, producto de la reforma constitucional (Ley № 20.050 de 2005), persiguió preservar la libertad de expresión y el derecho a la información junto con la "transparencia democrática, facilitando el control de los actos de los hombres públicos por parte de la ciudadanía": Historia de la Ley № 20.050, de 2005, p. 123.
} 
Por unA RESPONSABILIDAD CIVIL DE LOS MEDIOS DE COMUNICACIÓN COHERENTE CON EL RIESGO DE DIVULGACIÓN DE NOTICIAS FALSAS SOBRE PERSONAS PÚBLICAS

a un mayor riesgo de sufrir daño a consecuencia de la falsedad difamatoria que les afecte" 145 .

Pues bien, una forma adecuada de sopesar estos bienes jurídicos y zanjar la contienda a favor del derecho a la honra consiste en limitar la responsabilidad a las conductas notoriamente abusivas, a saber: la publicación de noticias falsas de mala fe, con desprecio de su verosimilitud o de modo en extremo negligente, dada la asimilación de la culpa lata al dolo en materias civiles.

La concreción de los riesgos ínsitos en la divulgación de hechos de interés social que atingen a quienes ocupan posiciones de poder y son constantemente examinados por la opinión pública, debería desencadenar la responsabilidad de los Medios si éstos actúan con culpa calificada ${ }^{146}$.

En efecto, "la manera de determinar si una conducta es ilícita es hacer una ponderación de valores, y, por decirlo así, el dolo, la intención de causar el daño, no es sino un elemento desfavorable más a añadir a nuestra balanza. El menosprecio expreso del bien jurídico protegido es una circunstancia que el Derecho tiene muy en cuenta para determinar si una conducta es lícita o no... Esta valoración de la intencionalidad como elemento a la hora de determinar la responsabilidad por daños rompe parcialmente la concepción de que el análisis de la corrección de la actividad del agente ha de ser puramente 'objetivo'"147.

La libertad de informar es una causal de justificación que confiere al agente un derecho a dañar y elimina la culpabilidad e ilicitud de su comportamiento. Sin embargo, mientras no abuse de su libertad, el daño que cause simplemente actualizará un riesgo intrínseco a una actividad no solo legítima sino alentada por el ordenamiento jurídico ${ }^{148}$.

El abuso se verificará si se divulgan informaciones falsas consciente o temerariamente.

"[E]n Derecho civil no importará normalmente si el hecho es doloso o negligente, porque el acto doloso supone ya un comportamiento negligente, y como de lo que se trata es de reparar un daño, da igual la intención del agente. Sin embargo, en ciertas ocasiones sí será relevante que el acto se haya realizado dolosamente, porque sin dolo la acción no es ilícita y, por tanto, no da lugar a indemnización. En última instancia, determinar si una conducta es ilícita o no

\footnotetext{
${ }^{145}$ Gertz v. Robert Welch, Inc., pp. 344-345.

146 Anguita (2005), pp. 25 y 408-409; Barros (2006), pp. 85-86, 112-113, 537-539 y 577-582; FedDERSEN (2008), pp. 85-86; PINO (2014); Daniel (2016), pp. 113-115.

${ }^{147}$ García-Ripoll (2008), pp. 55-56.

${ }^{148}$ Savatier (1951), p. 48; Karila de Van (1995), pp. 533-558.
} 
requiere una valoración global de todas las circunstancias concurrentes en la producción del daño"149.

En concreto, el dolo y la culpa grave permiten administrar la responsabilidad civil con mayor consciencia de la fricción entre el derecho a la honra de las personas públicas y la libertad de informar de los Medios ${ }^{150}$.

El abuso de la libertad de expresión se consumará si el titular difunde noticias a sabiendas de la inverosimilitud de los hechos informados, despreciando la posibilidad de que no sean ciertos o con suma imprudencia.

La intención de dañar -como un fin o como un medio para otro fin-debería definir el abuso del derecho a la libertad de informar ${ }^{151}$.

En efecto, el ordenamiento no acepta la utilización dolosa de una causal de justificación.

Pues bien, el indicio externo del abuso caracterizado por el dolo del agente es la inutilidad del acto ${ }^{152}$. Es decir, el titular ejerce su libertad de expresión con el solo propósito de denostar a otro o de lucrar con total indolencia hacia un daño que, previsible y probablemente, causaría y causó ${ }^{153}$.

Los Medios deben cerciorarse de la verosimilitud -no de la efectividad- de la información que pretenden difundir. El valor social y político de la libertad de informar sin censura previa, justifica la aplicación de un deber de cuidado más moderado en la comunicación de noticias atingentes a personas cuya reputación depende de la probidad con que cumplan las funciones públicas que les han sido encomendadas.

De ahí la conveniencia de acotar la responsabilidad a la publicación deliberada o muy desprolija de noticias carentes del más mínimo indicio de veracidad.

Es decir, el desprecio de la falsedad de la información publicada por los Medios los hace responsables de los daños, pues "las declaraciones falsas no tienen valor constitucional alguno... Ni la mentira intencional ni el error culpable promueven el interés de la sociedad en el debate 'desinhibido, robusto y abierto' de los asuntos públicos... Pero aunque la declaración errónea no merezca protección constitucional ella es inevitable en un debate libre... si se castiga el error se corre

\footnotetext{
${ }^{149}$ García-Ripoll (2008), p. 58.

150 Idéntico criterio ayuda a sopesar la libertad de competir y el principio de reparación integral. Los actos de competencia desleal -como el ejercicio frívolo de acciones judiciales- implican dolo o total desprecio hacia el rival: BARROS (2006), pp. 1047-1049; BANFI (2012), pp. 3-32, (2013) y (2017). Factor de imputación que podría extenderse a la responsabilidad civil por ilícitos anticompetitivos: BANFI (2011) y (2014).

151 VignON-BarRault (2004), p. 139.

152 RIPERT (1949), pp. 171-179.

153 VignON-BarRault (2004), pp. 150-151.
} 
el riesgo de inducir un ejercicio cauto y restrictivo de las libertades de expresión y prensa... Una regla de responsabilidad estricta que compela a los Medios de comunicación a garantizar la exactitud de las declaraciones de hecho puede conducir a una auto-censura intolerable $e^{\prime \prime 154}$.

Por el contrario, los Medios no debieran responder de los perjuicios emanados de la difusión de hechos verosímiles aunque en el litigio posterior se descubra que no eran efectivos ${ }^{155}$.

Como declaró el Tribunal Supremo español, "cuando la Constitución requiere que la información sea 'veraz' no está tanto privando de protección a las informaciones que puedan resultar erróneas -o sencillamente no probadas en juiciocuanto estableciendo un específico deber de diligencia sobre el informador, a quien se le puede y debe exigir que lo que transmita como 'hechos' haya sido objeto de previo contraste con datos objetivos, privándose, así, de la garantía constitucional a quien, defraudando el derecho de todos a la información, actúe con menosprecio de la veracidad o falsedad de lo comunicado. El ordenamiento no presta su tutela a tal conducta negligente, ni menos a la de quien comunique como hechos simples rumores o, peor aún, meras invenciones o insinuaciones insidiosas, pero sí ampara, en su conjunto, la información rectamente obtenida y difundida, aun cuando su total exactitud sea controvertible. En definitiva, las afirmaciones erróneas son inevitables en un debate libre, de tal forma que, de imponerse 'la verdad" como condición para el reconocimiento del derecho, la única garantía de la seguridad jurídica sería el silencio"156.

El mayor riesgo para la libertad de expresión en democracia proviene del Estado, a través de normas legales -como las que rigen en materia de propiedad, contratos y responsabilidad-y del poder judicial. Cada vez que un juez condena a los Medios a resarcir los daños infligidos con mero descuido a personas públicas con ocasión de la difusión de noticias que les atañen, la libertad de expresión claudica ante la honra, erigiéndose ésta en una propiedad infranqueable ${ }^{157}$.

Para evitar este riesgo nuestros jueces podrían usar un estándar de responsabilidad civil diferenciado, distinguiendo diversos grados de protección de la libertad de expresión respecto de la honra. Así, la reputación del común de las personas debe ser protegida mediante una regla de responsabilidad basada en la mera negligencia, mientras que la honra de las personas públicas afectadas por discursos ofensivos de los Medios no debería acarrear la responsabilidad

\footnotetext{
${ }^{154}$ Gertz v. Robert Welch, Inc., p. 340.

155 Barros (2006), pp. 581-582.

${ }^{156}$ STS 6/1988, cons. 5 . Criterio reiterado en fallos más recientes: YzQuierdo (2014), pp. 1396-1397.

157 SUNSTEIN (1993), pp. 38-39.
} 
de éstos salvo que hayan actuado "sabiendo que mentían o habiendo sido verdaderamente tontos en creer que decían la verdad"158.

En definitiva, si bien la justicia correctiva explica el contenido y la estructura del derecho privado ${ }^{159}$, éste también puede contribuir al bien común cada vez que el juez aplica los derechos fundamentales consagrados genéricamente en la Constitución sirviéndose de los principios, instituciones, reglas, estándares, categorías y conceptos del derecho privado.

El ejemplo más claro de la influencia de los derechos fundamentales sobre el derecho privado, y de la doble función que éste cumple, es la pugna entre la libertad de expresión y la reputación de personas públicas ${ }^{160}$.

El derecho privado puede servir al bien común si la jurisprudencia limita la responsabilidad civil de los Medios de la forma antes referida.

\section{Conclusión}

Las recientes sentencias nacionales en la materia develan una cierta aversión judicial al riesgo de que los Medios publiquen por equivocación afirmaciones falsas que afecten la reputación de personas públicas en asuntos de interés general.

Sin embargo, si la imputación de responsabilidad civil no es precedida por una ponderación reflexiva de los bienes jurídicos en conflicto -usando criterios similares a los elaborados por la jurisprudencia anglosajona-, la que permita decidir si la empresa periodística actuó razonablemente al difundir información a pesar de no haber corroborado su veracidad, o no es restringida mediante la exigencia de mala fe o temeraria indiferencia -la regla norteamericana- o la culpa lata equiparable al dolo, ello conllevará un riesgo mucho más grave para nuestra democracia, cual es, el de desalentar la actividad periodística en cuestiones de indudable interés público.

\section{BibLIOGRAFÍA}

Abeliuk Manasevich, René (2010): Las obligaciones (5a ed., Santiago, Editorial Jurídica de Chile), Tomo II.

Aedo Barrena, Cristián (2014): "El concepto normativo de la culpa como criterio de distribución de riesgos. Un análisis jurisprudencial", en: Revista Chilena de Derecho (Volumen 41, № 2), pp. 705-728.

\footnotetext{
158 SunStein (1993), pp. 9-10.

${ }^{159}$ WeINRIB (1995) y (2012).

160 Du Bois (2012), pp. 89-103.
} 
Por unA RESPONSABILIDAD CIVIL DE LOS MEDIOS DE COMUNICACIÓN COHERENTE CON EL RIESGO DE DIVULGACIÓN DE NOTICIAS FALSAS SOBRE PERSONAS PÚBLICAS

Alessandri Rodríguez, Arturo (1943): De la responsabilidad extracontractual en el derecho civil chileno (Santiago, Imprenta Universitaria).

(2013): De la compraventa y de la promesa de venta (2a ed., Santiago, Editorial Jurídica de Chile), T. I, Vol. I.

American Law INSTitute (1965-2017): Restatement (Second) of Torts ( ${ }^{\text {nd }}$ edition, Philadelphia, ALI).

AmunÁtegui Perelló, Carlos (2013): Derecho civil y medio ambiente. Un estudio de la teoría de las inmisiones y su aplicabilidad en el derecho chileno (Santiago, Editorial Legal-Publishing).

(2009): "No siendo contra derecho ajeno: hacia la formulación de una teoría de las inmisiones en nuestro Código Civil", en: Revista Chilena de Derecho (Volumen 36, № 3), pp. 505-525.

Anguita Ramírez, Pedro (2005): El derecho a la información en Chile. Análisis de la Ley No 19.733 sobre libertades de opinión e información y ejercicio del periodismo (Santiago, Editorial LexisNexis).

Baeza PInto, Sergio (2012): El seguro (4ª ed., Santiago, Editorial Jurídica de Chile.

BANFI DEL RíO, Cristián (2017): "De la función punitiva de la responsabilidad aquiliana en Francia: algunas implicancias para la comprensión del derecho de daños chileno", en: Revista de Derecho Universidad Austral de Chile (Volumen $\left.30, N^{0} 1\right)$, pp. 97-125.

(2014): "Acerca de la imputación de responsabilidad civil por ilícitos anticompetitivos entre rivales en Chile", en: Revista Chilena de Derecho (Volumen 41, No 1), pp. 37-58.

(2013): Responsabilidad civil por competencia desleal. Estudio de derecho chileno y comparado (Santiago, Editorial Legal Publishing).

(2012): "Por una reparación integral del daño extracontractual limitada a los hechos dolosos o gravemente negligentes", en: Revista lus et Praxis (Año 18, No 2), pp. 3-32.

(2011): "Defining the competition torts as intentional wrongs", en: Cambridge Law Journal (Volumen 70, № 1), pp. 83-112.

(2003): La asimilación de la culpa grave al dolo en la responsabilidad contractual (Santiago, Editorial LexisNexis).

Banfi del Río, Cristián; Gatica Rodríguez, María Paz y Salah Abusleme, María Agnes (2018), "Risk and Chilean Private Law", en: Dyson, Matthew (ed.), Regulating risk through private law (Cambridge, Intersentia), pp. 195-222.

BARAONA GonzÁlEz, Jorge (1999): El retraso en el cumplimiento de las obligaciones (Madrid, Dykinson). 
Barrientos Grandon, Javier (2012), Código Civil (Santiago, Editorial LegalPublishing), Tomo II.

BARROS, Enrique (2006): Tratado de responsabilidad extracontractual (Santiago, Editorial Jurídica de Chile).

(1984): "Reglas y principios en el derecho", en: Anuario de Filosofía Jurídica y Social ( $\left.N^{\circ} 2\right)$, pp. 269-281.

BECK, Ulrich (1999): La sociedad del riesgo global ( $2^{a}$ ed., Traduce. Jesús Alborés, Madrid, Siglo XXI Editores).

(1998): La sociedad del riesgo (Traduce. Jorge Navarro et al., Barcelona, Editorial Paidós).

Bercovitz Rodríguez-Cano, Rodrigo (2009): “Comentario al artículo $7^{\circ}$ del Código Civil", en Bercovitz Rodríguez-Cano, Rodrigo (coord.), Comentarios al Código Civil (Madrid, Editorial Aranzadi), BIB 2009\5227, pp. 1-4.

Brantt Zumarán, María Graciela (2010): El caso fortuito y su incidencia en el derecho de la responsabilidad civil contractual (Santiago, Editorial Legal-Publishing).

Carbonnier, Jean (2000): Droit civil. Les biens (19a ed., Paris, PUF), Tomo III.

Cárdenas Villarroel, Hugo (2016): "Función y alcance de interdictos posesorios especiales en el actual contexto normativo ambiental", en: Departamento de Derecho Privado Universidad de Concepción (ed.), Estudios de derecho civil XI (Santiago, Editorial Thomson Reuters), pp. 285-299.

Cea Egaña, José Luis (2012): Derecho constitucional chileno (2a ed., Santiago, Ediciones UC), Tomo II.

Claro Solar, Luis (1979): Explicaciones de derecho civil chileno y comparado ( $2^{\mathrm{a}}$ ed., Santiago, Editorial Jurídica de Chile), Tomo XII.

CONTESSE Singh, Jorge (2002): "Reglas y principios en Chile: ¿Jerarquía entre los derechos constitucionales?", en: Anuario de Filosofía Jurídica y Social ( No 20), pp. 53-93.

CORRAL TALCIANI, Hernán (2013): Lecciones de responsabilidad extracontractual ( $2^{a}$ ed., Santiago, Editorial Legal-Publishing).

(2010): Contratos y daños por incumplimiento (Santiago, Editorial Legal-Publishing).

(2006): "Sobre la responsabilidad civil de los periodistas y de los Medios de comunicación social por atentados a la honra, intimidad e imagen", en: Información Pública (Volumen 4, № 2), pp. 253-286.

Coutasse del Campo, Alberto e IturRa Astudillo, Fernando (1958): El caso fortuito ante el derecho civil (Santiago, Editorial Jurídica de Chile). 
Por unA RESPONSABILIDAD CIVIL DE LOS MEDIOS DE COMUNICACIÓN COHERENTE CON EL RIESGO DE DIVULGACIÓN DE NOTICIAS FALSAS SOBRE PERSONAS PÚBLICAS

Daniel Cruz, María de la Luz (2016): Libertad de prensa y daños: consideraciones en torno al estándar de cuidado aplicable a los Medios masivos de comunicación. Memoria de prueba para optar al grado de Licenciado en Ciencias Jurídicas y Sociales de la Universidad de Chile.

De la Maza Rivadeneira, Lorenzo (1933): "La teoría de la imprevisión", en: Revista de Derecho y Jurisprudencia (Tomo 30, $1^{\text {a }}$ Parte), pp. 73-158.

Díez, José Luis (1997): El daño extracontractual. Jurisprudencia y doctrina (Santiago, Editorial Jurídica de Chile).

Domínguez, Ramón (1990): "Consideraciones en torno a la noción de daño en la responsabilidad civil. Una visión comparatista", en: Revista de Derecho Universidad de Concepción (Año 58, N 188), pp. 125-168.

Domínguez Hidalgo, Carmen (2011): "Los derechos de la personalidad y el principio de reparación integral del daño", en Varas, Juan Andrés et al. (eds.), Estudios de derecho civil (Santiago, Editorial Legal-Publishing), Tomo IV, pp. 409-423.

(2010): "El principio de reparación integral del daño y su contenido: algunas consecuencias para el derecho chileno", en: Departamento de Derecho Privado Universidad de Concepción (coord.), Estudios de derecho civil V (Santiago, Editorial Legal-Publishing), pp. 671-685.

Du BoIs, François (2012): "Social purposes, fundamental rights and the judicial development of private law", en: Nolan, Donal y Robertson, Andrew (eds.), Rights and private law (Oxford, Hart), pp. 89-114.

Ducci Claro, Carlos (1971): Responsabilidad civil. Actividades peligrosas, hechos de las cosas, circulación de vehículos (Santiago, Editorial jurídica de Chile).

DWORKIN, Ronald (1978): Taking rights seriously (Cambridge, Massachusetts, HUP).

EPSTEIN, Richard (1986): "Was New York Times v. Sullivan wrong?", en: University of Chicago Law Review (Volumen 53), pp. 782-818.

EPSTEIN, Richard y SHARKEY, Catherine (2012): Cases and material on torts $\left(10^{\text {th }}\right.$ edition, New York, Wolters Kluwer).

Esser, Josef (1961): Principio y norma en la elaboración jurisprudencial del derecho privado (Traduce. Eduardo Valentí Fiol, Barcelona, Editorial Bosch).

Esteve, José (1999): Técnica, riesgo y derecho. Tratamiento del riesgo tecnológico en el derecho ambiental (Barcelona, Editorial Ariel).

Feddersen, Mayra (2008): "Responsabilidad civil y actividad periodística en Chile", en: Cuadernos de Análisis Jurídico (Volumen 4), pp. 71-94. 
Figueroa García-Huidobro, Rodolfo (2014): Privacidad (Santiago, Ediciones Universidad Diego Portales). Fueyo Laneri, Fernando (1953): Repertorio de voces y giros del Código Civil chileno (Madrid/Santiago, Revista de Derecho Privado).

Fueyo LANerl, Fernando (1954): "Algo sobre la teoría de la imprevisión", en: Revista de Derecho y Jurisprudencia (Tomo 60, $1^{\text {a }}$ Parte), pp. 89-108.

(1958): Derecho civil (Santiago, Roberts Impresora y Litografía Universal), Tomo IV, Volumen II).

Garay Opaso, Osvaldo y González Jara, Manuel (2008): Vida privada y honra frente a las libertades de opinión e información. El ejercicio del periodismo entre dos aguas (Santiago, Editorial Librotecnia).

García-Ripoll Montijano, Martín (2008): Imputación objetiva, causa próxima y alcance de los daños indemnizables (Granada, Editorial Comares).

Gatica Pacheco, Sergio (1959): Aspectos de la indemnización de perjuicios por incumplimiento del contrato (Santiago, Editorial Jurídica de Chile).

GidDENS, Anthony (1990): The consequences of modernity (Cambridge, Polity Press).

Gómez Laplaza, María del Carmen (2006): "Abuso del derecho", en: Revista de Derecho Privado ( $N^{\circ}$ 90), pp. 3-74.

Grisolía CORBATÓN, Francisco (2004): Libertad de expresión y derecho a la honra (Santiago, Editorial LexisNexis).

HART, Herbert (1961): The concept of law (Oxford, Clarendon Press).

Historia de LA Ley No 20.050, Primer Trámite Constitucional: Senado, Primer Informe de Comisión de Constitución, Legislación, Justicia y Reglamento (6/11/2001), Sesión 12, Legislatura 345, Boletines No 2.526-07 y No 2.534-07.

Hohfeld, Wesley (1913): "Some fundamental legal conceptions as applied in judicial reasoning", en: Yale Law Journal (Volumen 23), pp. 16-59.

Holmes, Oliver W. (1891/1964): The common law (2a ed., Traduce. Fernando Barrancos, Madrid, Tipográfica Editora Argentina).

Kalven, Harry Jr. (1964): "The New York Times case: a note on the 'central meaning of the First Amendment'", en: The Supreme Court Review, pp. 191-221.

Karila de VAN, Juliana (1995): "Droit de nuire", en: Revue Trimestrielle de Droit Civil, pp. 533-558.

LANDES, William y POSNeR, Richard (1987): The economic structure of tort law (Cambridge, Mass., HUP).

LarRaín PÁez, Cristián (2011): "Algunas cuestiones relevantes sobre el derecho al honor y la responsabilidad civil, en particular, sobre el daño moral, el 
Por unA RESPONSABILIDAD CIVIL DE LOS MEDIOS DE COMUNICACIÓN COHERENTE CON EL RIESGO DE DIVULGACIÓN DE NOTICIAS FALSAS SOBRE PERSONAS PÚBLICAS

artículo 2331 del Código Civil, y la legitimación activa", en: Revista Chilena de Derecho Privado (No 17), pp. 143-189.

López Santa María, Jorge (2010): Contratos. Parte general (5 ${ }^{\mathrm{a}}$ ed., Santiago, Editorial Legal-Publishing).

Martín-Casals, Miquel (2010): "Technological change and the development of liability for fault: A general introduction", en: Martín-Casals, Miquel (ed.), The development of liability in relation to technological change, en: Bell, John e Ibbetson, David (series ed.), Comparative studies in the development of the law of torts in Europe (Cambridge, CUP), Volumen 4, pp. 1-39.

Matus Valencia, Hernán (1955): El problema de los riesgos en los contratos. Memoria de prueba para optar al grado de Licenciado en Ciencias Jurídicas y Sociales de la Universidad de Chile.

Mazeaud, Henri; Mazeaud, Léon; Mazeaud, Jean, y Chabas, François (1998): Leçons de droit civil. Obligations. Théorie générale (9a ed., Paris, Montchrestien).

Momberg Uribe, Rodrigo (2010): "Teoría de la imprevisión: La necesidad de su regulación legal en Chile", en: Revista Chilena de Derecho Privado ( $\left.N^{\circ} 15\right)$, pp. 29-64.

Nogueira Alcalá, Humberto (2002): El derecho a la libertad de opinión e información y sus límites: honra y vida privada (Santiago, Editorial LexisNexis).

Peñailillo Arévalo, Daniel (2006): Los bienes. La propiedad y otros derechos reales (Santiago, Editorial Jurídica de Chile).

(2000): "La revisión judicial de obligaciones y contratos en la reforma del Código Civil (La lesión y la imprevisión)", en: Revista de Derecho Universidad de Concepción (Año 68, N² 208), pp. 209-237.

Pino Emhart, Alberto (2014): "Cambios recientes en la defensa de interés público (privilegio Reynolds) respecto a la acción de responsabilidad por difamación del derecho inglés", en: Revista Chilena de Derecho Privado (№ 23), pp. 263-274.

Politoff Lifschitz, Sergio; Matus Acuña, Jean Pierre, y Ramírez Guzmán, María Cecilia (2009): Lecciones de derecho penal chileno. Parte especial (2a ed., Santiago, Editorial Jurídica de Chile).

Michaels, Ralf (2006): "The functional method of comparative law", en: Reimann, Mathias y Zimmermann, Reinhard (eds.), The Oxford handbook of comparative law (Oxford, OUP), pp. 339-382.

Ríos Ossa, Roberto (2015): "Artículo 513 T). Definición de riesgo", en Schiele Manzor, Carolina (ed.), El contrato de seguro. Comentarios al Título VII, 
Libro II del Código de Comercio (Santiago, Editorial Thomson Reuters), pp. 150-167.

RIPERT, Georges (1949): La règle morale dan les obligations civiles (4a ed., Paris, LGDJ).

Rojas Calderón, Christian (2014): "Los riesgos, las funciones del derecho ambiental ante éstos, y su control por medio de entidades privadas colaboradoras de la gestión ambiental", en: Revista de Derecho de la Pontificia Universidad Católica de Valparaíso ( ${ }^{\circ}$ 43), pp. 549-582.

SAVATIER, René (1951): Traité de la responsabilité civile en droit français (Paris, LGDJ), Tomo I.

SCHAUER, Frederick (2006): "Do cases make bad law?", en: University of Chicago Law Review (Volumen 73), pp. 883-918.

SHAveLL, Steven (1987): Economic analysis of accident law (Cambridge, Mass., HUP).

SierRa IribarRen, Lucas (1997): "Pluralismo y comunicación social: libertad de expresión y dos conceptos de libertad", en: Revista de Derecho Universidad Austral de Chile (Volumen 8, suplemento especial), pp. 17-26.

SPEKER, Adam y McMahon, Felicity (2014): "Defamation", en: Jones, Michael (ed.), Clerk \& Lindsell on torts $\left(21^{\text {st }}\right.$ edition, London, Sweet \& Maxwell Thomson Reuters), pp. 1531-1672.

SunsteIn, Cass (1993): Democracy and the problem of free speech (New York, The Free Press).

TAPIA SUÁREZ, Orlando (2007): De la responsabilidad civil en general y de la responsabilidad delictual entre los contratantes ( $3^{\text {a }}$ ed., Santiago, Editorial LexisNexis).

Tapia Rodrícuez, Mauricio (2013): Caso fortuito en el derecho civil chileno (Santiago, Editorial Thomson Reuters).

(2005): Código Civil 1855-2005. Evolución y perspectivas (Santiago, Editorial Jurídica de Chile).

Tisné Niemann, Jorge (2017): Las inmisiones. Protección de la propiedad frente a ruidos, humos, olores y otros conflictos de vecindad (Santiago, Editorial Thomson Reuters).

Tushnet, Mark (2014): "New York Times v. Sullivan around the World", en: Alabama Law Review (Volumen 66, № 2), pp. 337-356.

Vignon-Barrault, Aline (2004): Intention et responsabilité civile (Marseille, Presses Universitaires d'Aix Marseille), Tomo I. 
Por UNA RESPONSABILIDAD CIVIL DE LOS MEDIOS DE COMUNICACIÓN COHERENTE CON EL RIESGO DE DIVULGACIÓN DE NOTICIAS FALSAS SOBRE PERSONAS PÚBLICAS

VINEY, Geneviève (1995): Traité de droit civil. Introduction à la responsabilité ( $2^{\mathrm{a}}$ ed., Paris, LGDJ).

WeinRIB, ERnest (2012): Corrective Justice (Oxford, OUP). (1995): The idea of private law (Cambridge, Massachusetts, HUP).

YzQuierdo Tolsada, Mariano (2014): "Daños a los derechos de la personalidad (honor, intimidad y propia imagen)", en: Reglero Campos, Fernando y Busto Lago, José Manuel (coord.), Tratado de responsabilidad civil ( $5^{\mathrm{a}}$ ed., Navarra, Thomson Reuters), Tomo II, pp. 1365-1498.

ZwEIGERT, Konrad y KöTz, Hein (1998). An introduction to comparative law ( $3^{\text {rd }}$ ed., Traduce. Tony Weir, Oxford, OUP).

\section{NORMA JURÍDICA CITADA}

Decreto Ley $N^{\circ}$ 425, sobre abusos de publicidad. Diario Oficial, 20 de marzo de 1925.

Decreto No 853 (5/01/1991), Ministerio de Relaciones Exteriores, aprueba Convención Americana sobre Derechos Humanos, denominada "Pacto de San José de Costa Rica". Diario Oficial, 5 de enero de 1991.

Defamation Act 2013. 25 de abril de 2013.

Ley $\mathrm{N}^{0} 16.643$, sobre abusos de publicidad. Diario Oficial, 4 de septiembre de 1967.

Ley $N^{\circ} 19.733$, sobre libertad de opinión e información y ejercicio del periodismo. Diario Oficial, 4 de junio de 2001.

Ley $\mathrm{N}^{0}$ 20.050, sobre reforma constitucional que introduce diversas modificaciones a la Constitución Política de la República. Diario Oficial, 26 de agosto de 2005.

Proyecto que modifica el Código Civil, con el objeto de regular la procedencia de la indemnización del daño moral por atentados a la honra, la vida privada y la imagen personal - Boletín No 9107-07 (2013): Cámara de Diputados, Legislatura 361ª, Sesión 74ª, 12 de septiembre de 2013, pp. 94-96, disponible en https://www.camara.cl/pley/pley_detalle. aspx?prmID=9516\&prmBL=9107-07. Fecha consulta: 20.11.2017.

\section{JURISPRUDENCIA CITADA}

Bordachar con Pontificia Universidad Católica de Chile-Canal 13 (2010): Tribunal Constitucional 23 de septiembre de 2010, rol No 1463-2009 (requerimiento de inaplicabilidad por inconstitucionalidad art. 2331). 
Bonnick v. Morris [2003] 1 A.C. 300 (acción de difamación).

Calvo Red de Televisión Chilevisión S.A. (2015): $27^{\circ}$ Juzgado Civil de Santiago 20 de abril de 2012, rol No 22596-2007; Corte de Apelaciones de Santiago 26 de junio de 2014, rol No 4591-2012; Corte Suprema 20 de agosto de 2015, rol No 22835-2014 (acción de indemnización de perjuicios).

Camiroaga con Passalacqua (2011): Tribunal Constitucional 15 de marzo de 2011, rol No 1679-2010 (requerimiento de inaplicabilidad por inconstitucionalidad art. 2331).

Carrasco con Rojas (2017): Tribunal Constitucional 19 de mayo de 2017, rol $\mathrm{N}^{\circ}$ 2915-2015 (requerimiento de inaplicabilidad por inconstitucionalidad art. 2331).

Carvajal con Oyarzún (2012): Corte de Apelaciones de Santiago 23 de noviembre de 2012, rol № 4213-2011 (acción de indemnización de perjuicios).

Celle v. Filipino Reporter Enterprises, 209 F.3d 163 (2000) (acción de difamación).

Contra Bonvallet (2007): Corte Suprema 4 de julio de 2007, rol No 4642-2006 (querella criminal por delito de injurias graves).

Contra Lara y Otros (2013): Corte Suprema 21 de agosto de 2013, rol № 83932012 (querella criminal por delitos art. 161-A CP).

Contra Quijada y Otros (2016): Corte Suprema 11 de agosto de 2016, rol $\mathrm{N}^{0}$ 38159-2016 (querella criminal por delitos art. 161-A CP).

Contreras con Corporación de Televisión de la Universidad Católica de Chile (2011): 20 Juzgado Civil de Santiago 28 de enero de 2011, rol № 280732007 (acción de indemnización de perjuicios).

Cordero con Chilevisión (2014): $6^{\circ}$ Juzgado Civil de Santiago, 31 de mayo de 2011, rol No 15656-2006; Corte de Apelaciones de Santiago 12 de junio de 2013, rol No 4303-2011; Corte Suprema 19 de marzo de 2014, rol No 58442013 (acción de indemnización de perjuicios).

STS 6/1988, 21 de enero de 1988 (recurso de amparo).

Curtis Publishing Co. v. Butts, 388 U.S. 130 (1967) (certiorari).

Elberg con Bacigaluppi (2015): Tribunal Constitucional 25 de agosto de 2015, rol No 2747-2014 (requerimiento de inaplicabilidad por inconstitucionalidad art. 2331).

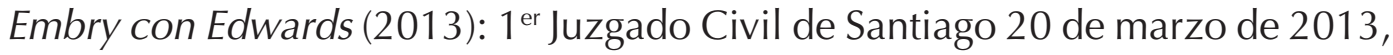
rol No 9270-2010; Corte de Apelaciones de Santiago 28 de octubre de 2014, rol No 8983-2013 (acción de indemnización de perjuicios).

STS 4544/2016 (recurso de casación en tutela civil del derecho fundamental al honor). 
Por unA RESPONSABILIDAD CIVIL DE LOS MEDIOS DE COMUNICACIÓN COHERENTE CON EL RIESGO DE DIVULGACIÓN DE NOTICIAS FALSAS SOBRE PERSONAS PÚBLICAS

Flood v. Times Newspapers Ltd, [2012] 2 A.C. 273 (acción de difamación).

García-Huidobro con Pinto y Otro (2013): Tribunal Constitucional 29 de agosto de 2013, rol No 2410-2013 (requerimiento de inaplicabilidad por inconstitucionalidad art. 2331).

Gertz v. Robert Welch, Inc., 418 U.S. 323 (1974) (certiorari).

González con Empresa Periodística La Cuarta S.A. (2015): $28^{\circ}$ Juzgado Civil de Santiago 14 de julio de 2014, rol No 19302-2012; Corte de Apelaciones de Santiago 12 de marzo de 2015, rol № 6597-2014 (acción de indemnización de perjuicios).

Harte-Hanks Communications v. Connaughton, 491 U.S. 657 (1989) (certiorari).

Jameel v. Wall Street Journal Europe SPRL, [2007] 1 A.C. 359 (acción de difamación).

Horrocks v. Lowe, [1975] A.C. 135 (acción de difamación).

Loutchansky v. Times Newspapers Ltd, [2002] Q.B. 321 (acción de difamación).

Loyola con Empresa El Mercurio SAP: 25 Juzgado Civil de Santiago 26 de octubre de 2015, rol No 13478-2012; Corte de Apelaciones de Santiago 13 de julio de 2016, rol No 433-2016; Corte Suprema13 de junio de 2017, rol No 65403-2016 (acción de indemnización de perjuicios).

Loyola con Empresa Periodística La Cuarta S.A.: $5^{\circ}$ Juzgado Civil de Santiago 28 de octubre de 2014, rol No 14560-2012; Corte de Apelaciones de Santiago 15 de abril de 2015, rol No 438-2015; Corte Suprema 13 de julio de 2015, rol No 6736-2015 (acción de indemnización de perjuicios).

Luksic con Martorell (1993): Corte de Apelaciones de Santiago 31 de mayo de 1993, rol No 983-1993; Corte Suprema, 15 de junio de 1993, rol № 210531993 (recurso de protección).

Molina con Empresa Periodística del Norte S.A. (2015): Corte de Apelaciones de Antofagasta 30 de noviembre de 2015, rol № 159-2015 (acción de indemnización de perjuicios).

Muñoz con Municipalidad de Hualpén (2017): Corte Suprema 20 de septiembre de 2017, rol No 5813-2017 (acción de indemnización de perjuicios).

New York Times v. Sullivan, 376 U.S. 254 (1964) (certiorari).

Ominami con Urbano (2009): Tribunal Constitucional 19 de abril de 2009, rol $\mathrm{N}^{\mathrm{0}}$ 1185-2008 (requerimiento de inaplicabilidad por inconstitucionalidad arts. 2331 y 40 inc. $2^{\circ}$, Ley $N^{0} 19.733$, de 2001).

Panday con Gordon, [2006] 1 A.C. 427 (acción de difamación).

Pérez con Red de Televisión Chilevisión S.A. (2015): $28^{\circ}$ Juzgado Civil de Santiago 28 de enero de 2015, rol No 10926-2012; Corte de Apelaciones de Santiago 
21 de agosto de 2015, rol № 4078-2015; Corte Suprema 12 de noviembre de 2015, rol № 22902-2015 (acción de indemnización de perjuicios).

Prado con TVN (2017): $20^{\circ}$ Juzgado Civil de Santiago 22 de enero de 2016, rol 14413-2012; Corte de Apelaciones de Santiago 7 de diciembre de 2016, rol № 3309-2016; Corte Suprema 3 de agosto de 2017, rol № 6897-2017 (acción de indemnización de perjuicios).

Proceso de inconstitucionalidad de oficio art. 2331 (2011): Tribunal Constitucional 24 de mayo de 2011, rol № 1723-2010.

Reynolds v. Times Newspapers Ltd, [2001] 2 A.C. 127 (acción de difamación). STS 4964/2004 (recurso de casación en tutela civil del derecho fundamental al honor).

St. Amant v. Thompson, 390 U.S. 727 (1968) (certiorari).

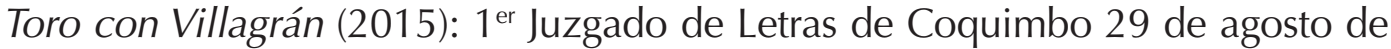
2013, rol № 2083-2011; Corte de Apelaciones de La Serena 31 de julio de 2015, rol No 600-2014; Corte Suprema 28 de octubre de 2015, rol № 137042015 (acción de indemnización de perjuicios).

Valdés con Irarrázabal (2008): Tribunal Constitucional 10 de junio de 2008, rol $N^{\circ}$ 943-2007 (requerimiento de inaplicabilidad por inconstitucionalidad art. 2331).

Van Rysselberghe con Ávila (1999): Corte Suprema 5 de julio de 1999, rol No 1586-1999, CL/JUR/813/1999 (querella criminal por delitos de calumnia e injurias graves).

Yarur con Yarur (2012): Tribunal Constitucional 19 de junio de 2012, rol № 2071 2011 (requerimiento de inaplicabilidad por inconstitucionalidad art. 2331).

Yarur con Yarur (2016): Tribunal Constitucional, 26 de enero de 2016, rol № 2860-2015 (requerimiento de inaplicabilidad por inconstitucionalidad art. 2331). 